\title{
Cervical cancer prevention and treatment research in Africa: a systematic review from a public health perspective
}

Sarah Finocchario-Kessler ${ }^{1 *}$, Catherine Wexler ${ }^{1}$, May Maloba ${ }^{2 *}$, Natabhona Mabachi ${ }^{1}$, Florence Ndikum-Moffor ${ }^{3}$ and Elizabeth Bukusi ${ }^{2,4,5}$

\begin{abstract}
Background: Women living in Africa experience the highest burden of cervical cancer. Research and investment to improve vaccination, screening, and treatment efforts are critically needed. We systematically reviewed and characterized recent research within a broader public health framework to organize and assess the range of cervical cancer research in Africa.

Methods: We searched online databases and the Internet for published articles and cervical cancer reports in African countries. Inclusion criteria included publication between 2004 and 2014, cervical cancer-related content pertinent to one of the four public health categories (primary, secondary, tertiary prevention or quality of life), and conducted in or specifically relevant to countries or regions within the African continent. The study design, geographic region/country, focus of research, and key findings were documented for each eligible article and summarized to illustrate the weight and research coverage in each area. Publications with more than one focus (e.g. secondary and tertiary prevention) were categorized by the primary emphasis of the paper. Research specific to HIV-infected women or focused on feasibility issues was delineated within each of the four public health categories.

Results: A total of 380 research articles/reports were included. The majority (54.6\%) of cervical cancer research in Africa focused on secondary prevention (i.e., screening). The number of publication focusing on primary prevention (23.4 \%), particularly HPV vaccination, increased significantly in the past decade. Research regarding the treatment of precancerous lesions and invasive cervical cancer is emerging (17.6\%), but infrastructure and feasibility challenges in many countries have impeded efforts to provide and evaluate treatment. Studies assessing aspects of quality of life among women living with cervical cancer are severely limited (4.1\%). Across all categories, $11.3 \%$ of publications focused on cervical cancer among HIV-infected women, while $17.1 \%$ focused on aspects of feasibility for cervical cancer control efforts.
\end{abstract}

Conclusions: Cervical cancer research in African countries has increased steadily over the past decade, but more is needed. Tertiary prevention (i.e. treatment of disease with effective medicine) and quality of life of cervical cancer survivors are two severely under-researched areas. Similarly, there are several countries in Africa with little to no research ever conducted on cervical cancer.

Keywords: Cervical cancer, Africa, Systematic review, Prevention, Treatment, Quality of life, Feasibility challenges

\footnotetext{
* Correspondence: Skessler2@kumc.edu

${ }^{1}$ Department of Family Medicine, University of Kansas Medical Center,

Kansas City, USA

${ }^{2}$ Family AIDS Care and Education Services, Kenya Medical Research Institute,

Kisumu, Kenya

Full list of author information is available at the end of the article
} 


\section{Background}

Cervical cancer is the second most common cancer among women worldwide, with an estimated 528,000 new cases and 266,000 deaths among women each year [1]. A disproportionate number of these cases (85\%) and deaths (87\%) occur among women living in low and middle income countries [1]. Women living with HIV are at increased risk of developing cervical cancer [2-4] and experience more rapid progression of the disease [5-7]. Since 1993, cervical cancer was classified as an AIDS-defining illness [8].

The World Health Organization (WHO) advocates a comprehensive approach to cervical cancer prevention and control to identify opportunities to deliver effective interventions [9]. Cervical cancer-related research has increased significantly over the past decade, representing biomedical, behavioral, and policy level findings. Existing review papers synthesize knowledge and advancements for multiple areas of focus within the larger effort of cervical cancer prevention and treatment, e.g., biomarkers for cervical cancer [10, 11], HPV vaccination for young adolescent women [12-15], and feasible approaches to screen and treat adult women in low resource settings [16-20]. The purpose of this systematic review is to assess and characterize recent research within a broader public health framework, utilizing well-known public health terminology to organize and assess the range of efforts to respond to cervical cancer. In this context, these include: Primary Prevention (preventing the initial onset of cervical cancer), Secondary Prevention (early detection by screening and treatment of precancerous cervical lesions), Tertiary Prevention (treatment of cervical cancer to reduce morbidity and mortality), and Quality of Life (post-treatment care or palliative care for those without treatment options) among women in African countries. Literature highlighting feasibility considerations (accessibility, affordability, health care infrastructure, and provider training) and findings specific to HIV-infected women are integrated as appropriate in each public health category.

\section{Primary prevention}

Vaccination is one of the most commonly used public health strategies to reduce the risk of infection and minimize the prevalence of the disease-causing agent (HPV) in the environment. Nearly all cases (99.7\%) of cervical cancer are caused by human papillomavirus (HPV) [21], particularly types 16 and 18 which cause more than two-thirds of all precancerous cervical lesions and cervical cancers [22, 23]. HPV is one of the most common sexually transmitted infections, with up to $75 \%$ of sexually active people estimated to be infected at some point during their lives [24]. Fortunately, two vaccines are approved for use. The bivalent vaccine protects against HPV types 16 and 18. The quadrivalent vaccine protects against HPV types 16 and 18 and also types 6 and 11, which cause $90 \%$ of genital warts [25]. Since HPV infection often occurs shortly after the onset of sexual activity (over $35 \%$ of women are infected within 2 years of initiating sexual activity) [26-28], vaccination campaigns should target 9-13 year old youth, prior to sexual debut. The vaccines are over $95 \%$ effective at preventing HPV infection caused by vaccine-type HPV when the full three course dose is given over six months $[29,30]$. Since 2014, the WHO recommends a two-dose regimen for girls and boys aged 9-13 (quadrivalent vaccine) or aged 9-14 (bivalent vaccine) [31], which is not yet licensed in all countries, but reduces the follow-up burden while maintaining strong protective coverage [32-35].

The WHO recommends the inclusion of HPV vaccination in national immunization programs provided HPV represents a public health priority and vaccine delivery is feasible and cost-effective [31]. Unfortunately, HPV vaccination is not yet available in many African countries. By August 2014, only 58 countries had introduced HPV vaccination for girls into their national immunization program [31]. While the majority of these are high-resource countries, a few low to middle income countries in Africa including Rwanda, South Africa, Lesotho, and Uganda [36] have also introduced national HPV vaccines. In 2013, the Global Alliance for Vaccines and Immunizations (GAVI) began providing support for HPV vaccinations to eligible countries and will support demonstration projects in 23 countries, of which ten have been launched, primarily in sub-Saharan Africa [37, 38]. However, barriers to vaccination (i.e. concerns about the safety of the vaccine, provider reservations about recommending vaccination for younger girls, limited awareness of the relationship between HPV and cervical cancer, and varied parental acceptance of the HPV vaccine [39-42]) result in inconsistent vaccine uptake, globally [13, 43]. Recent efforts to vaccinate young boys have received less focus, but may help indirectly protect girls by reducing the risk of re-infection with HPV and will help prevent other HPV-related morbidities for men including penile cancer, anal cancer, oropharyngeal cancer, and genital warts [44].

Other primary prevention strategies to reduce HPV infection and cervical cancer include delaying sexual debut, reducing the number of lifetime sexual partners, and increasing condom use [45]. In addition to reducing HIV acquisition and transmission, medical male circumcision is also protective for HPV in males [46-48], which reduces the risk of initial or re-infection of HPV among women.

\section{Secondary prevention}

Screening for early detection and treatment is a cornerstone of secondary prevention. Early diagnosis and treatment of cervical pre-cancerous lesions prevents up to $80 \%$ of cervical cancers in high resource countries where cervical cancer screening is routine [49]. In higher 
income countries, cervical cytology (Pap smear) in which cervical cells are examined in order to detect cervical intraepithelial neoplasia (CIN) became part of routine care in the 1940's [50]. For women who screen positive for premalignant cervical lesions (i.e., CIN), a confirmatory colposcopy is required [51]. Cervical cytology, however, is not a feasible method of screening in many African countries given the required level of medical and laboratory infrastructure and trained personnel, multiple return visits with poor patient tracking strategies, and availability of such services often limited to capital cities. The proportion of women in sub Saharan Africa reporting a pelvic exam and pap test in the previous three years is very low (1.0 \% in Ethiopia to $23.2 \%$ in South Africa), with $40 \%$ of women in Tunisia to $94 \%$ of women in Malawi having never received a pelvic exam $[52,53]$.

The more feasible, and WHO-approved, strategy for cervical cancer screening in low resource settings is visual inspection with acetic acid (VIA) or visual inspection with Lugol's iodine (VILI). After applying acetic acid or Lugol's iodine directly on the cervix, pre-cancerous and cancerous lesions turn white, making them visible to the naked eye [54]. This method has high sensitivity among HIVinfected and uninfected women $[55,56]$. Results are immediate, thus women who screen positive for precancerous lesions can theoretically be offered cryotherapy treatment during the same visit, or a "screen and treat" approach, if the health facility has the capacity. This strategy has been shown cost-effective, affordable, and an ideal first-line treatment for CIN of any grade when the cervical lesion size and location allows the cryoprobe tip to make adequate contact [57-60]. This 'screen and treat' strategy can avoid the burden of costly follow up visits, significant delays in treatment, and loss to follow up [61, 62].

Cryotherapy can be performed at the primary care level by mid-level providers, such as nurses or midwives, who can be trained to perform cryotherapy with a minimum of supplies and equipment $[58,63]$. In developed countries, cryotherapy is approximately $90 \%$ effective for all grades of CIN after 1 year [64]. The most commonly employed treatment options for pre-cancerous lesions are removal of diseased tissue using loop electrosurgical excision procedure (LEEP) which requires local anesthetic $[65,66]$ or by freezing the affected tissue with cryotherapy [57]. These treatments are typically performed by trained providers in outpatient clinics at provincial or referral level hospitals. Cold-knife conization [65] can be used to remove lesions that cannot be effectively treated with LEEP or cryotherapy.

The optimal frequency of screening is every $3-5$ years depending on screening method [67], or within 3 years for women living with HIV [68]. If a woman can be screened only once in her lifetime, the most strategic age is between 30 and 39 years [69]. Recent estimates on national rates of cervical cancer screening are not available for many African countries, but a number of studies report self-reported screening rates to be low (8.3-64 \%) [70-74], but slightly higher among women accessing HIV-care (9.4-80\%) [72, 75, 76]. A 2008 populationbased survey in 57 countries estimated $19 \%$ of women in developing countries were screened for cervical cancer in the preceding three years [77]. In addition to infrastructure and resource-related barriers, awareness of cervical cancer among reproductive-aged women remains low [70, 78-81] and an inadequate proportion of health care providers has been trained to provide high quality screening $[82,83]$. Efforts have been made in many countries to integrate cervical cancer screening in HIV care, but routine provision is still limited [77, 84]. HPV DNA testing represents an emerging strategy for early detection of cervical cancer, particularly if technology innovations can permit point-of-care testing which will eliminate requirements for laboratory infrastructure and technical support $[68,85]$. HPV DNA testing must be made affordable for widespread use in African countries.

\section{Tertiary prevention}

Women with abnormal cervical tissue are diagnosed with either precancerous lesions or invasive cervical cancer, both of which require treatment. Severe cervical dysplasia that remains undiagnosed or untreated can develop into invasive cancer [86]. Unfortunately, a significant proportion of women (56-80.6\%) [(Kenya) [87]; (Tanzania) [88]; (Nigeria) [89]) are identified once their cervical cancer is at an advanced stage [90].

Staging the severity of invasive cervical cancer requires assessment of the vagina, parametrium, urinary bladder and rectum by a combination of clinical and endoscopic procedures to determine the stage of progression (I - IVB) [91]. Inadequate laboratory facilities and personnel shortages may result in treatment decisions being made without proper diagnoses or adequate information. Treatments for invasive cervical cancer can include a range and combination of strategies including hysterectomy (requires surgical facilities), radiotherapy (external and intracavitary radiotherapy infrastructure), and chemotherapy [68, 92, 93]. The availability of these options are typically limited to capital cities in several African countries or, in some cases, not available at all [94]. Consequently, palliative care with symptom control and support may be the most likely option for severely late stage cervical cancer or for women with less advanced disease, but who cannot afford or access treatment. Studies indicate that only between $24-67 \%$ of those diagnosed with cervical cancer in Tanzania, Zimbabwe, Uganda or Nigeria received some form of treatment (either radiotherapy or hysterectomy) [88, 89, 95, 96], with women in advanced stages (III and IV) of disease 
progression [96] and women co-infected with HIV [88] less likely to be treated.

Cervical cancer mortality rates in low resource countries are nearly three times as high as rates experienced in high resource settings $[1,97,98]$. Survival data for cervical cancer in African countries are limited. Estimated 5-year survival for women diagnosed with cervical cancer in 7 African countries between 2005 - 2009 was $56.3 \%$ (range 19.5-96 \%) [99]. Among women receiving treatment (radiotherapy and/or surgery), survival probabilities at one year post diagnosis ranged from 73.9-90.4 \% and decreased progressively to $32.5 \%$ by four years $[87,95,96$, 100]. Without treatment, observed survival is 58.6 at 1 year and decreases to $31.1 \%$ by 4 years $[95,96]$. Studies from Uganda and Zimbabwe suggest that although treatment with radiotherapy improves patient survival two to three years after diagnosis, this advantage disappears in later years $[95,96]$.

\section{Quality of life}

Cervical cancer is associated with psychological and physical morbidities that negatively impact quality of life $[101,102]$. Age-adjusted, daily-adjusted life years (DALY) lost from cancer in African countries is consistently higher than those of high resource countries [103]. The estimated DALY lost from cervical cancer in subSaharan Africa is 641 years per 100,000 women [103]. Quality of life is most compromised among patients with inoperable cervical cancer treated by radiotherapy, with a majority reporting deterioration in physical, emotional, social, and economic support [104], and the highest risk for long-term dysfunction of bladder, bowels and psychosocial consequences [105]. Other treatment related side-effects such as extended vaginal bleeding and chronic radiation enteritis can affect physical and social aspects of their quality of life [106, 107].

Significant changes in the sexual domain resulting in marital discordance [104] and waning partner support over the course of treatment and survival [108] have been reported in Kenya and South Africa. While such data are limited for low-resource settings, literature reviews from high resource countries document posttreatment changes in body image, vaginal function, sexual satisfaction, and sexual relationship with partner; indicating a clear need for better integration of sexuality rehabilitation into routine clinical care [109-111]. Furthermore, there are few treatment options available that preserve fertility [92, 112-114], which can have significant implications for young women given the personal and cultural importance of childbearing [115]. Open communication about fertility and sexuality-related issues with cervical cancer patients of reproductive-age should occur prior to treatments to help shape expectations and quality of life during recovery [113].
In most African countries, there is a long historical precedent of providing palliative care at home by family or community members [116]. Although strengthened by the AIDS response, palliative care efforts still fail to provide effective pain relief [91], with the availability and accessibility of opioids for pain relief severely limited in African countries [117]. In a study among Nigerian cancer patients (including cervical cancer patients), the presence of pain was significantly associated with depressive and anxiety symptoms, suicidal ideation, poor sleep, impaired concentration, lack of opportunity for leisure, dissatisfaction with health, poor overall quality of life, poor ability to get around and the need for excessive medical treatment to function in daily life [118]. In 2011, only four African countries had integrated palliative care into their cancer strategic plans and two others had stand-alone national palliative care policies [119]. Pain management for cancer patients should not be neglected as countries develop and adapt their response to cervical and other cancers.

\section{Feasibility considerations}

Governments grapple with challenges posed by limited funds and competing healthcare priorities including a heavy burden from both infectious and chronic diseases. While the African Cancer Registry Network (AFCRN), launched in 2012, supports 25 cancer registries in 19 member countries in sub Saharan Africa [120, 121], many still lack established cancer prevention and control health policies [94, 122]. The geographic distribution of cancer treatment centers with cytology laboratories, radiotherapy and chemotherapy infrastructure severely limits accessibility for residents in more rural areas [49, 54, 85]. A 2009 situational analysis of east, central, and southern African countries estimated that only $4 \%$ of institutions had equipment to perform outpatient treatment modalities such as cryosurgery [123]. This demand for scarce services typically results in long waiting periods (median 3.8 months in Ethiopia [100]) for treatment. The costs for return hospital visits, pathology reports, and subsequent treatment are beyond the resources of the majority of women in these settings [124]. According to a recent study, infrastructure investment of approximately $\$ 59$ million would be required to equip every cervical cancer screening facility with cryotherapy equipment in 23 highincidence sub-Saharan African countries [125] to be able to employ the recommended screen and treat approach [51]. Estimating the ability to screen nearly 20 million women over a 10 year period in these targeted countries, the costs for screening (VIA) would be less than \$10 USD per woman, and the costs for treatment by cryotherapy or LEEP would range between \$38 to \$71 USD per woman [125]. Systems to track and refer women who test positive and support treatment retention are also lacking; 
diminishing the return on investment of current screening efforts.

\section{Methods}

We searched several online databases including PubMed/ MEDLINE (NCBI), Embase (Elsevier), African Index Medicus (AIM), and Google Scholar for published studies. Our search also included highly relevant global and government reports not published in peer-reviewed journals. Inclusion criteria included publication between 2004 and 2014, cervical cancer-related content pertinent to one of the four public health categories (primary, secondary, tertiary prevention or quality of life), and conducted in or specifically relevant to countries or regions within the African continent. Reference sections of articles were reviewed to identify additional eligible articles. Searches for each of the four focus areas were conducted separately, including combinations of the following search words: 1) primary prevention $[H P V$ vaccination, Africa, cervical cancer prevention, HPV prevention, cost effectiveness, medical male circumcision, coverage], 2) secondary prevention [cervical cancer screening, Africa, cervical cancer secondary prevention, HPV screening, screen and treat, male $H P V$ screening], 3) tertiary prevention [cervical cancer treatment, Africa, SSA, pre-cancerous lesions, invasive cervical cancer, management of invasive cervical cancer in Africa, cervical cancer survival, HIV, access to treatment, challenges,], and 4) quality of life [cervical cancer, quality of life, Africa, sexual function, palliative care, relationship challenges, partner support, treatment recovery]. A separate search was conducted to identify research focused on issues of feasibility and infrastructure [health care infrastructure for cervical cancer, Africa, accessibility, affordability, training health care providers, provider knowledge, feasibility, HPV vaccine, screening, screen and treat, treatment]. Rather than creating a section dedicated to feasibility issues, these were integrated into the preceding categories, depending on the focus of the article.

The study design, geographic region/country, focus of research, and key findings were documented for each eligible article. Articles and reports were maintained in four separate spreadsheets (reflecting the four priority categories) and later combined to review and eliminate any duplication and to determine the best grouping for articles that may have covered more than one primary category. The articles and reports under each primary category were then analyzed and refined to highlight sub-themes, type of literature (original research, review article, lessons learned or policy paper) and the country or geographic region of research, Tables 1, 2, 3 and 4.

One thousand five hundred six records were reviewed through database and Internet searches (Fig. 1). Among those 389 met the criteria for inclusion. After eliminating nine duplicates among the categories, a total of 380 records

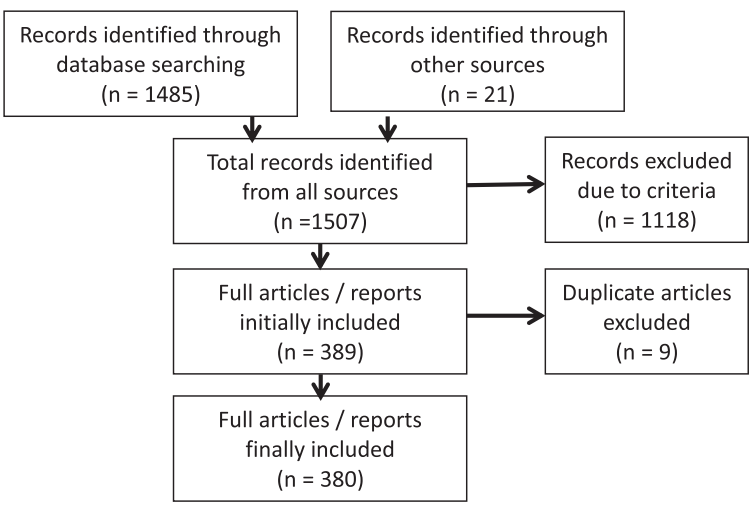

Fig. 1 PRISMA flow diagram of the number of searches yielded, excluded, and reviewed

were included in this review. Publications have been organized according to four targeted categories of public health interest to illustrate the weight and coverage of research in each area. Publications that span more than one area of focus (e.g. secondary and tertiary prevention) were categorized by the primary emphasis of the paper.

This systematic review did not require approval from an ethical review board or informed consent with participants as research efforts were limited to the review and analysis of previously published or presented cervical cancer research in African countries.

\section{Results \\ Primary prevention}

Table 1 reports the predominate focus of each article describing primary prevention. Of all 89 publications identified, 76 (85\%) focused on the HPV vaccination for the prevention of HPV/cervical cancer. Only 13 (15\%) focused on other prevention methods (mainly male circumcision but also condom use and microbicides), of which eight were performed in Uganda by the same study group. We could not find any study that examined the prevention of HPV and/or cervical cancer by delayed sexual debut, abstinence, and/or limiting the number of sexual partners. Considering the multiple foci of each paper, rather than just the primary focus, 17 talked about the cost-effectiveness or estimated impact of HPV vaccinations; 40 had a focus on acceptability, knowledge, and/or attitudes [12, 39-41, 126$152]$; ten had a focus on uptake and/or retention [43, 152160]; five had a focus on populations affected by HIV [47, 161-163]; four had a focus on males [132, 138, 150, 158]; four had a focus on safety and immunogenicity $[161,162$, $164,165]$; one on adverse events [166]; and three on policy [167-169]; ten on male circumcision [46-48, 170-176]; two on lubricants, gels, and/or microbicides [177, 178], one on diaphragms [177]; and one on condoms [179].

Of the 76 publications about HPV vaccination, the researchers and/or study received some support from the 
Table 1 Primary Prevention Research, $n=89$

Focus

Primary

Prevention

HPV Vaccination

Knowledge/Acceptability/Attitudes
$(N=29)$

Uptake/Retention $(N=10)$

Feasibility $(N=23)$

Cost/cost effectiveness $[14,170,181,214$,

261-269]

Estimated impact [270-272]

Provider knowledge/training [128, 129, 133,

140-143]

HIV $(N=2)$

Males $(N=1)$

Other $(N=11)$

Safety/Immunogenicity $(n=2)[164,165]$

Adverse Events $(n=1)$ [166], Barriers $(n=1)$

Policy $(n=6)[168,169,273-276]$, Conference

Summary $(n=1)[152]$

Primary Prevention (HPV Vaccine)

Total $=76$

Non-Vaccine

Prevention

Male Circumcision $(N=10)$

Condoms $(N=1)$
Literature type

Countries/Geographic Regions Included

25 Original research $[39-41,126,127$

130-132, 134-137, 139, 144-151, 158,

$180,256,257$

2 Review Articles [12, 15]

0 Lessons Learned

South Africa [130, 139, 148, 150, 151, 158], Malawi [41],

Mali [132, 147], Cameroon [134, 144], Kenya [39, 145, 257$]$

2 Policy Papers [167, 258]

6 Original research $[43,153,155,157,159$, Uganda [153, 259, 261], Lesotho [43, 155], Cameroon [43, 155, 160]

1 Review Articles [259]

3 Lessons Learned $[154,156,260]$

0 Policy

21 Original research $[128,129,133$,

$140-143,170,181,214,261,263-272]$

2 Review Articles [14, 262]

0 Lessons Learned

0 Policy

2 Original research $[161,162]$

0 Review Articles

0 Lessons Learned

0 Policy

1 Original research [138]

0 Review Articles

0 Lessons Learned

0 Policy

3 Original research [164-166]

2 Review Articles [42, 152]

0 Lessons Learned

6 Policy $[168,169,273-276]$

59 Original research

6 Review Articles

3 Lessons Learned

8 Policy

156], Tanzania [155,160], Uganda [155, 157]. Kenya [155],

South Africa [159], Rwanda [154, 260]

Tanzania [14, 181, 267, 269], Uganda [14, 267, 271],

Sub-Saharan Africa [262, 264], Mali [263, 270], Nigeria [128,

140, 141, 143, 265], South Africa [129, 142, 214], GAVI-eligible

countries [266, 268, 272], Kenya [267, 271], Mozambique [271]

Zimbabwe [271], Guinea [170], Cameroon [133]

South Africa $[161,162]$

Uganda [138]

Uganda [166, 168, 274], Senegal [164], Tanzania [164, 165], Low-Middle Income Countries [42, 273, 276], Middle East/

North Africa [275], Sub-Saharan Africa [152, 169]

South Africa 12, Uganda 12, Tanzania 10, Nigeria 8, Cameroon 6, Kenya 6, Mali 4, Low-Middle Income Countries 3, GAVI

Eligible Countries 3, Lesotho 2, Rwanda 2, sub-Saharan Africa

4, Malawi 1, Botswana 1, Ghana 1, Zambia 1, Morocco 1, Ivory

Coast 1, Mozambique 1, Zimbabwe 1, Middle East/North

Africa 1, Guinea 1

10 Original research $[46-48,171-176,277]$ Uganda $[47,48,171-174,176,277]$, South Africa $[46,175]$

0 Review Articles

0 Lessons Learned

0 Policy

1 Original research [179]

South Africa [179]

0 Review Articles 
Table 1 Primary Prevention Research, $n=89$ (Continued)

0 Lessons Learned

0 Policy

Lubricant Gel, Microbicides and/or Diaphragm

$(N=2)$

Review Articles

South Africa [178], Zimbabwe [177]

0 Policy

Primary Prevention (Non-Vaccine)

13 Original research

Uganda (8), South Africa (4), Zimbabwe (1) 
pharmaceutical companies that manufacture HPV vaccinations in 16 (21 \%) of the studies [43, 126, 142, 153, 155-157, 160-162, 164-166, 170, 180, 181]. All studies that looked at safety/immunogenicity of the vaccines in HIV-infected [161, 162] and HIV-uninfected [164, 165] women were funded by pharmaceutical companies.

Knowledge/awareness and acceptability of the HPV vaccine was often reported together and assessed in many different countries in SSA and among many different populations. While acceptability of HPV vaccination tends to be high, knowledge and awareness of the vaccination is low, even amongst health care workers. There is a glaring lack of literature regarding HPV vaccination among HIVpositive populations and among males. Despite some data indicating HPV's role in other cancers (i.e. penile, anal, throat and mouth), all vaccination programs have focused solely on cervical cancer prevention. The few studies that focused on males emphasized their ability to influence $\mathrm{HPV}$ vaccine decision making in females or HPV vaccination in males to help protect females from cervical cancer. Direct benefits for men's health (i.e. reductions in genital warts, and penile, anal, throat/mouth cancers) were not highlighted.

Geographically, South Africa and Uganda contributed the most research, representing 18 and $23 \%$ of all primary prevention articles, respectively, and were represented in both vaccination and non-vaccination articles.

\section{Secondary prevention}

We identified a significant number of publications $(n=$ 208) focused on various aspects of secondary prevention of cervical cancer. Table 2 reports the predominant focus of each article. The primary focus of the 208 published articles include: 46 (22\%) on screening test performance; 16 (8\%) on screen-and-treat program implementation and/ or outcomes; 28 (13\%) on screening feasibility including infrastructure, provider knowledge and attitudes, and costs; 59 (29\%) on women's knowledge about, attitudes towards, and uptake of cervical cancer; 18 (8\%) on cervical cancer screening specifically among HIV + women; 3 (1.5\%) on aspects of $\mathrm{HPV} /$ cervical cancer screening relevant to males; 23 on program (excluding screen-and-treat programs) or intervention implementation and/or outcomes; and 15 focused on other categories. A total of 65 (32\%) reported on observed or self-reported uptake (ranging between $0-100 \%$; mean $=25 \%$; median $=15 \%$ ) among different populations.

VIA/VILI and HPV testing were the most commonly evaluated screening tests, both individually and when compared with other tests. Of the 15 articles examining the performance of HPV testing, 12 compared different sample collection methods (i.e. self vs. physician collected samples [182-189]; dried cervical spots [190, 191]; tampons $[188,191,192])$. Sensitivity and specificity of each test ranged from 25-91.7\% [193, 194] and 64.6-98.2\% $[195,196]$ for VIA, 44-97.7 \% [194, 195] and 68.9-97.3\% [196, 197] for VILI, 31-90.4 \% [193, 195] and 84.5-96.9\% [193, 198] for cytology, and 63.9-100\% [192, 198] and 73-96.6 \% [184, 198] for HPV DNA testing, respectively. The sensitivity and specificity of self-collected and physician collected HPV samples were similar, making it useful for women who may be reluctant to undergo a pelvic exam.

Most (53 \%) of the articles focusing on a screen-andtreat approach assessed VIA/VILI and then treatment with cryotherapy. While many reported on barriers, challenges, and lessons learned from this approach [199-202], most indicated that screen-and-treat methods were safe, acceptable, and feasible in African settings and reduced loss-to-follow up after a positive screening test. One commentary [203] was critical of screen-and-treat approaches, stating a lack of evidence of safety which can compromise acceptability and potential effectiveness of all screening programs. Articles focusing on awareness and utilization were mostly cross-sectional studies and reported low levels of knowledge and awareness of cervical cancer screening, but generally positive attitudes [204, 205]. This was supported by higher uptake (59.6-100 \%) of screening among women who were offered the test as part of an intervention [71, 75, 84, 206, 207].

The majority of articles in the feasibility section focused on provider knowledge, awareness, and acceptability. Although knowledge of cervical cancer and screening methods was higher amongst health care workers compared to the general population [208-211], utilization of screening among female health care workers remained low (4-41\%). Cervical cancer screening programs were extremely cost-effective, either implemented by themselves $[59,212,213]$ or in combination with other cervical cancer prevention programs [214]. However, infrastructure challenges reported in both feasibility and program/ policy implementation articles (long travel distances to screening and care centers, lack of gynecologists and laboratory pathologists and other manpower shortages, equipment problems, poor record keeping, inadequate patient follow-up, and delayed testing results [215-220]) make wide scale implementation and utilization challenging in many African settings.

Only three articles were identified that focused primarily on males and cervical cancer screening in Africa [221-223]. Similarly, while several articles included HIV-positive women in their analyses [72, 224, 225], only 16 focused exclusively on cervical cancer screening among HIV-positive women. Despite a higher positivity rate among HIV-infected women [224, 226], knowledge of cervical cancer screening [75, 225, 227, 228] and uptake [72, 75, 227, 228] is still low. Integrating HIV care and cervical cancer screening [229-231] and utilizing 
Table 2 Secondary prevention research, $n=208$

\begin{tabular}{lll}
\hline & Primary focus & Literature type \\
\hline Secondary & Screening Test Performance $(N=46)$ & 41 Original Research [182, 184-186, 188-198, \\
Prevention & 11 VIANILI [194, 196, 197, 232, 278-284] & 232, 278-293, 295, 296, 298-303] \\
& 15 HPV Testing [163, 182-192, 285-287] & 4 Review Article [16, 187, 294, 297] \\
& 3 Cytology [288-290] & Lessons Learned \\
& 1 Colposcopy [291] & 1 Policy Papers [163] \\
& 16 Comparison of 2+ tests [16, 193, 195, & \\
& $198,292-303]$ &
\end{tabular}
Countries/Geographic Regions Included

Africa (2) [285, 297], Developing Countries (4) [16, 284, 294, 302], Angola (1) [197], Botswana (1) [232], Burkina Faso (5) [194, 280, 282, 291, 298], Cameroon (4) [182, 193, 286, 300], Democratic Republic of Congo (3) [195, 198, 296], Republic of the Congo (6) [191, 194, 280, 282, 291, 298], Egypt (2) [186, 278], Gambia (1) [192], Ghana (1) [288], Guinea (5) [194, 280, 282, 291, 298], Ivory Coast (1) [190], Kenya (2) [184, 301], Mali (5) [194, 280, 282, 291, 298], Niger (5) [194, 280, 282, 291, 298], Nigeria (4) [279, 287, 289, 293], Rwanda (1) [294], South Africa (7) $[163,183,187,188,290,292,299]$, Tanzania (2) [196, 295]

Screen-and-Treat (SNT) $(N=16)$ 8 VIA then Cryotherapy [63, 199-201, 304-307]

5 Other SNT methods [61, 308-311]

3 Guidelines/Overview [51, 202, 203]

Feasibility $(N=28)$

2 Infrastructure [215, 220]

8 Provider Knowledge/Training/Attitudes

$[60,82,83,208-211,312-322]$

8 Cost/Cost-effectiveness [59, 125, 212-214, 323-325]

Awareness and Utilization $(N=59)$

44 Knowledge, Attitudes, Uptake [53, 70, 72

$74,78-80,204-207,225,326-357]$

15 Determinants of Uptake [62, 73, 358-370]

10 Original Research [61, 63, 200, 201, 305, 307-311]

2 Review [203, 304]

2 Lessons Learned [199, 202]

2 Policy $[51,2831,217]$

26 Original Research $[59,83,125,208-215$,

220, 312-325]

2 Review [60, 82]

0 Lessons Learned

0 Policy

59 Original Research $[53,62,70,72-74,78-80$, 204-207, 225, 326-370]

0 Review

0 Lessons Learned

0 Policy

17 Original Research $[75,77,84,226-230$

371-379]

1 Review [231]

0 Lessons Learned

0 Policy

9 Test Performance [371-379]
3 Knowledge, Attitudes, Uptake [75, 227, 228]

1 Screen-and-Treat [226]

Males and HPV Screening $(N=3)$

1 Knowledge and Beliefs [221], 1 Male Partne

Support [222], 1 Penile HPV Detection [223]

Other $(N=38)$

23 Program/Policy Implementation [54, 71,

216-219, 224, 380-395]

3 Screening Follow-Up [396, 397] and

Side-effects [398]

3 Original Research [221-223]

0 Review

0 Lessons Learned

0 Policy

17 Original Research $[71,216,217,219,224,380,381$, Africa (3) [391, 400, 405], Developing Countries (7) [54, 69, 85, 383-385, 388, 395-398, 403, 404]

14 Review [54, 69, 85, 123, 382, 391, 392, 394, 399,

$400,402,405-407]$

4 Lessons Learned [218, 386, 387, 393]

5 Overview of Current Situation [123, 399-402]

3 Policy [389, 390, 401]

7 Other Ethical Issues [403] message development

[404] overviews,[69, 85, 405, 406] publication output [407]

Total

173 Original Research

(1) Africa (1) [203], Botswana (1) [307], Ghana (1)

[63], Kenya (1) [61], Madagascar (1) [306], Malawi (1) [306]

Nigeria (2) [306, 311],South Africa (2) [308, 310], Tanzania (1)

[306], Uganda (2) [200, 306], Zambia (7) [199, 201, 202,

304-306, 309]

Africa (3) [82, 125, 212], Cameroon (1) [313], Ghana (1) [323] Ivory Coast (1) [208], Kenya (2) [59, 325], Nigeria (11) [83, 211 $220,312,315-317,319-321]$, South Africa (6) $[59,213,214$, 318, 324, 325], Tanzania (1) [209], LRC [60]

Global (1) [368], Developing Countries (1) [328], Botswana (3) [72, 205, 349], Cameroon (1) [74], Ghana (2) [70, 326], Kenya (5) [204, 335, 340, 355, 358], Malawi (1) [53], Mozambique (1) [207], Morocco (1) [365], Nigeria (18) [78, 79, 225, 332-334, $337,338,342,344-346,348,351,352,363,366,367]$, South Africa (12) [80, 327, 329, 330, 341, 347, 353, 356, 360, 361, 369] Sudan (1) [343], Tanzania (5) [62, 336, 362, 364, 370], Tunisia

Global (1) [231], Burkina Faso (1) [373], Cameroon (1) [230], Kenya (4) $[229,374,376,378]$, Nigeria (3) $[75,84,227]$, South Africa (6) [226, 228, 371, 373, 375, 377], Uganda (1) [379], Tanzania (1) [77]

Ghana (1) [221], Kenya (1) [223], Uganda (1) [222]

Africa (3) [391, 400, 405], Developing Countries (7) [54, 69, 85 , 123, 382, 392, 406], Middle East/North Africa (1) [399], Ghana
(2) 217,401$]$, Ivory Coast (1) [224], Kenya (2) [384, 403], Mali (1) [383], Mozambique (1) [216], Nigeria (6) [386-388, 393, 396, 398], South Africa (11) [71, 218, 219, 381, 385, 390, 394, 395, 402, 404, 407], Sudan (1) [389] 
Table 2 Secondary prevention research, $n=208$ (Continued)

$$
N=208
$$

23 Review Article

6 Lessons Learned

6 Policy Papers
Global (3), Africa (9), Developing Countries (11), Middle East/

, Angola (1), Botswana (5), Burkina Faso (6),

Gameroon (7), Congo (9), Egypt (2), Gambia (1), Ghana (8),

Guinea (5), Ivory Coast (3), Kenya (17), Madagascar (1), Malaw
(2), Mali (6), Morocco (1), Mozambique (2), Niger (5), Nigeria

(43), Rwanda (1), South Africa (45), Sudan (2),Tanzania (9),

Tunisia (1), Uganda (4), Zambia (7), 
telemedicine [232] may provide viable methods for providing cervical cancer screening to HIV-positive women.

Geographically, the countries with the most research on secondary prevention were South Africa $(n=45)$, Nigeria $(n=43)$, and Kenya $(n=17)$. Countries were not evenly represented by category of secondary prevention. In several cases, a country was well-represented within one category but not in the others. For example, well represented in the screening test performance category were Republic of the Congo $(n=6)$ Guinea $(n=5)$, and Niger $(n=5)$, yet these countries were not represented within any of the other categories.

\section{Tertiary prevention}

We identified $n=67$ articles highlighting aspects of tertiary prevention of cervical cancer in African countries, reported in Table 3. The primary focus of published studies and reports included: 7 (10\%) on treatment of precancerous lesions, 8 (12\%) on diagnosis and staging,
$6(9 \%)$ on treatment for invasive cervical cancer, 8 (12\%) on survival outcomes, 23 (34\%) on HIV and cervical cancer, and $14(21 \%)$ regarding the feasibility of providing cervical cancer treatment. Treatment programs for cervical cancer are limited in most countries in Africa, as is research contributing outcome data, lessons learned, and implementation recommendations. Late diagnosis was routinely documented in several African countries among both HIV+ and HIV-uninfected women, with the proportion diagnosed with stage III or higher ranging from 56 to $90 \%$ [87, 88, 233, 234]. Suboptimal management of symptomatic patients (in frequent gynecologic exams and appropriate referrals) further exacerbates the challenge of late diagnosis [234].

The treatment sections for precancerous lesions and invasive cervical cancer are delineated by treatment strategy to indicate areas receiving more or less research focus. Studies describing outcomes or evaluating treatment strategies for precancerous lesions included loop electrical

Table 3 Tertiary prevention research, $n=67$

\begin{tabular}{|c|c|c|c|}
\hline \multicolumn{2}{|l|}{ Focus } & \multirow{2}{*}{$\begin{array}{l}\text { Literature type } \\
5 \text { Original research [311, } \\
408-411] \\
2 \text { Review Articles [57, 412] } \\
0 \text { Lessons Learned } \\
0 \text { Policy }\end{array}$} & \multirow{2}{*}{$\begin{array}{l}\text { Countries/Geographic Regions Included } \\
\text { Kenya (1) [411], South Africa (3) [408-410], } \\
\text { SSA (2) [57, 412], Nigeria (1) [311] }\end{array}$} \\
\hline $\begin{array}{l}\text { Tertiary } \\
\text { Prevention }\end{array}$ & $\begin{array}{l}\text { Treatment of Pre-Cancerous lesions } \\
\quad 3 \text { LLETZ [408-410] } \\
2 \text { Cryotherapy }[57,411] \\
2 \text { Comparison LEEP/Cryotherapy }[311,412] \\
N=7\end{array}$ & & \\
\hline & $\begin{array}{l}\text { Late Diagnosis/Staging } \\
N=8\end{array}$ & $\begin{array}{l}8 \text { Original research }[88,233, \\
234,365,413-416] \\
0 \text { Review Articles } \\
0 \text { Lessons Learned } \\
0 \text { Policy }\end{array}$ & $\begin{array}{l}\text { Nigeria (3) [413-415], Morocco (1) [365], } \\
\text { Tunisia (1) [416], Zimbabwe (1) [233], } \\
\text { Tanzania (1) [88], South Africa (1) [234] }\end{array}$ \\
\hline & $\begin{array}{l}\text { Treatment of Invasive Cervical Cancer } \\
2 \text { Surgery }[417,418] \\
3 \text { Radiotherapy }[419-421] \\
2 \text { Combination therapy }[422,423] \\
N=7\end{array}$ & $\begin{array}{l}5 \text { Original research [417, 418, 420, } \\
421,423] \\
1 \text { Review Articles [422] } \\
1 \text { Lessons Learned [419] } \\
0 \text { Policy }\end{array}$ & $\begin{array}{l}\text { SSA (1) [422], South Africa (3) [418, 420, 423], } \\
\text { Uganda (1) [421], Senegal (1) [419], } \\
\text { Nigeria (1) [417] }\end{array}$ \\
\hline & $\begin{array}{l}\text { Survival } \\
N=8\end{array}$ & $\begin{array}{l}6 \text { Original research }[87,95,100, \\
424-426] \\
2 \text { Review Articles }[427,428] \\
0 \text { Lessons Learned } \\
0 \text { Policy }\end{array}$ & $\begin{array}{l}\text { Malawi (1) [424], Uganda (2) [425, 428], } \\
\text { Gambia (1) [428], Ethiopia (1) [100], } \\
\text { South Africa (1) [426], Zimbabwe (1) [95], } \\
\text { Kenya (1) [87], Egypt (1) [427] }\end{array}$ \\
\hline & $\begin{array}{l}\text { HIV and treatment } \\
8 \text { HIV and CIN }[235,236,240-242,244,429,430] \\
8 \text { HIV and ICC }[238,239,243,246,431-434] \\
7 \text { HIV/Treatment of CIN and ICC }[239,245,247, \\
248,435-437] \\
N=23\end{array}$ & $\begin{array}{l}22 \text { Original research }[235,236, \\
238-248,429-433,435-437] \\
1 \text { Review Articles [434] } \\
0 \text { Lessons Learned } \\
0 \text { Policy }\end{array}$ & $\begin{array}{l}\text { South Africa (11) [240, 242, 243, 245, 247, } \\
248,429,432,433,436,437], \text { Kenya (5) } \\
{[235,236,239,244,430], \text { Uganda (1) [238], }} \\
\text { Global/SSA (3) [241, 246, 434], Cote 'Ivoire } \\
\text { (1) [431], Senegal (1) [435] }\end{array}$ \\
\hline & $\begin{array}{l}\text { Feasibility } \\
1 \text { Access/Awareness/Health Policy [255] } \\
6 \text { Training needs [92, 438-442] } \\
5 \text { Infrastructure needs [443-447] } \\
2 \text { Costs [448, 449] } \\
N=14\end{array}$ & $\begin{array}{l}10 \text { Original research } \\
1 \text { Review Articles [445] } \\
0 \text { Lessons Learned } \\
0 \text { Policy Papers } \\
2 \text { Meeting report }[92,442,447] \\
1 \text { Book Chapter }[255]\end{array}$ & $\begin{array}{l}\text { Africa (4) [441-443, 447], Kenya (1) [438], } \\
\text { Botswana (1) [444], Nigeria (1) [439], SSA (4) } \\
{[92,255,445,446], \text { Morocco (1) [448], Tunisia }} \\
\text { (1) [449], South Africa (1) [440] }\end{array}$ \\
\hline & $N=67$ & $\begin{array}{l}57 \text { Original research } \\
7 \text { Review Articles } \\
1 \text { Lessons Learned } \\
0 \text { Policy Papers } \\
2 \text { Meeting report } \\
1 \text { Book Chapter }\end{array}$ & $\begin{array}{l}\text { Kenya (8), South Africa (20), SSA (10), } \\
\text { Nigeria (6), Morocco (2), Tunisia (2), } \\
\text { Zimbabwe (2), Tanzania (1), } \\
\text { Uganda (4), Senegal (2), Malawi (1), } \\
\text { Ethiopia (1), Gambia (1), Egypt (1), } \\
\text { Cote d'Ivoire (1), Botswana (1) }\end{array}$ \\
\hline
\end{tabular}


excision procedure (LEEP) vs cryotherapy $(n=2)$, large loop excision of the transformation zone (LEETZ) $(n=3)$, and cryotherapy $(n=2)$. These treatment strategies were found to be well accepted [235, 236]. Studies regarding treatment for invasive cervical cancer included surgery $(n$ $=2)$, radiotherapy $(n=3)$ and combined radiochemotherapy $(n=2)$. This dearth of research reflects the limited capacity for cervical cancer treatment in African countries. According to the African Organization for Research and Training in Cancer (AORTIC) published in 2013, $22 \%$ of the 54 countries in Africa have no access to any form of anti-cancer therapies, which include surgical oncology, chemotherapy and radiation [237]. Among women who do begin treatment, loss to follow up continues to be a problem $[61,238,239]$.

The largest proportion of articles was specific to conditions and outcomes of HIV+ women with CIN or cervical cancer, followed by an emphasis on feasibility considerations for providing treatment. HIV+ women were more likely to present with CIN or cervical cancer at an earlier age [240], have higher grade CIN [241, 242], faster progression [243], more likely to experience CIN reoccurrence after treatment [236], and have poorer treatment and survival outcomes [238, 243, 244]. Antiretroviral therapy was shown to improve treatment outcomes for CIN and cervical cancer [245-248]. While feasibility articles were more comprehensive in nature, we categorized them according to the primary feasibility issue discussed: training needs of health care personnel on cervical cancer management $(n=6)$, the lack of medical infrastructure and scarcity of equipment to provide treatment $(n=5)$, and more generally, issues of access and awareness $(n=1)$ and costs $(n=2)$. While provider training for cervical cancer screening is slowly improving, multidisciplinary clinicians (pathologist, oncologists, radiologists) for the treatment of advanced cancer are far too few to meet the current demand [92, 237]. It's important to note that many of the tertiary prevention articles also addressed feasibility concerns in the discussion sections, but this subsection reflects articles with a primary focus on feasibility.

The majority of research on tertiary prevention for cervical cancer was conducted in South Africa and Nigeria, yet research from countries in West, East and Southern Africa were also represented. $82 \%$ were original research articles, $11 \%$ review articles and the remaining $7 \%$ were a combination of reports and commentary articles.

\section{Quality of life}

While there were a significant number of publications focusing on various aspects of quality of life among cervical cancer patients and survivors in the United States, Europe, and an increasing number from Taiwan, we found only $n=16$ publications from countries in Africa. Publications were organized into the following areas of focus: 8 (50 \%) on quality of life (physical, psychological, emotional, social, and spiritual), 5 (31\%) on palliative care, 1 (6\%) on partner support, and 2 (13\%) on symptoms and complications, see Table 4.

Among the seven publications describing quality of life outcomes, five studies reported the patient perspective and 1 study included data from both cervical cancer patients and caregivers. In regard to the timing of quality of life assessments, approximately half of these research studies included patients actively receiving treatment (typically radiotherapy) and the other half were receiving

Table 4 Quality of life research, $n=16$

\begin{tabular}{|c|c|c|c|}
\hline \multicolumn{2}{|l|}{ Focus } & \multirow{2}{*}{$\begin{array}{l}\text { Literature type } \\
6 \text { Original research }[101,104,118,450-452] \\
2 \text { Review Articles [103, 249] } \\
0 \text { Lessons Learned } \\
0 \text { Policy Papers }\end{array}$} & \multirow{2}{*}{$\begin{array}{l}\text { Countries/Geographic Regions Included } \\
\text { South Africa (2) [450, 451], Kenya (1) [104], } \\
\text { Nigeria (2) [101, 118], Sudan (1) [452], } \\
\text { Global-12 world regions (1) [103], Uganda } \\
\text { (3) }[249,450,451]\end{array}$} \\
\hline Quality of Life & $\begin{array}{l}\text { Quality of Life Outcomes } \\
N=8\end{array}$ & & \\
\hline & $\begin{array}{l}\text { Palliative Care } \\
N=5\end{array}$ & $\begin{array}{l}3 \text { Original research [250, 252, 253] } \\
1 \text { Review Articles [251] } \\
0 \text { Lessons Learned } \\
1 \text { Policy [117] }\end{array}$ & $\begin{array}{l}\text { Nigeria (1) [250], sub-Saharan Africa (1) [253], } \\
\text { Africa (2) [117, 251], South Africa (1) [252], } \\
\text { Uganda (1) [252] }\end{array}$ \\
\hline & $\begin{array}{l}\text { Partner Support } \\
N=1\end{array}$ & $\begin{array}{l}1 \text { Original research [108] } \\
0 \text { Review Articles } \\
0 \text { Lessons Learned } \\
0 \text { Policy }\end{array}$ & South Africa (1) [108] \\
\hline & $\begin{array}{l}\text { Symptoms and complications } \\
N=2\end{array}$ & $\begin{array}{l}2 \text { Original research }[107,254] \\
0 \text { Review Articles } \\
0 \text { Lessons Learned } \\
0 \text { Policy }\end{array}$ & Nigeria (1) [107], Uganda (1) [254] \\
\hline & $\begin{array}{l}\text { Total } \\
N=16\end{array}$ & $\begin{array}{l}12 \text { Original research } \\
3 \text { Review Articles } \\
0 \text { Lessons Learned } \\
1 \text { Policy Paper }\end{array}$ & $\begin{array}{l}\text { Global (1), SSA (3), South Africa (4), Kenya (1), } \\
\text { Nigeria (4), Sudan (1), Uganda (5) }\end{array}$ \\
\hline
\end{tabular}


palliative care. A recent review article estimated ageadjusted, daily-adjusted life years lost attributed to various types of cancer, including cervical cancer, in sub-Saharan Africa and other global regions. Five studies focused on palliative care for cancer patients (specific to or including cervical cancer patients) in Africa highlighting challenges to provide adequate pain management [117, 249, 250], and training to optimize palliative care for cancer patients [251, 252], including one review article [253]. Only one study directly addressed partner support for cervical cancer patients [108]. One study assessed urologic complications among women with advanced cervical cancer in Uganda prior to treatment [254], and another assessed Cisplatin based chemotherapy for treatment of long term vaginal bleeding [107]. The majority of these studies was conducted in Nigeria, South Africa, and Uganda or had a sub-Saharan Africa regional focus.
Despite the heavy burden of disease and limited access to cervical cancer treatment, research regarding multiple quality of life issues for women, their partners, and caregivers is still limited for countries in Africa. A notable gap in the literature is attention to fertility-related concerns and the impact of the disease and its treatment on women's bodies, sexual function, and relationships.

\section{Distribution of cervical cancer research in Africa}

Eligible articles and reports either focused globally $(n=4)$, on low or middle income countries (LMIC) $(n=14)$, the sub Saharan/African region $(n=27)$, and targeted multiple $(n=27)$ or single $(n=308)$ countries in Africa. A total of $n=30$ countries in Africa were represented by at least one publication. Figure 2 illustrates the density of cervical cancer research publications by country. This excludes

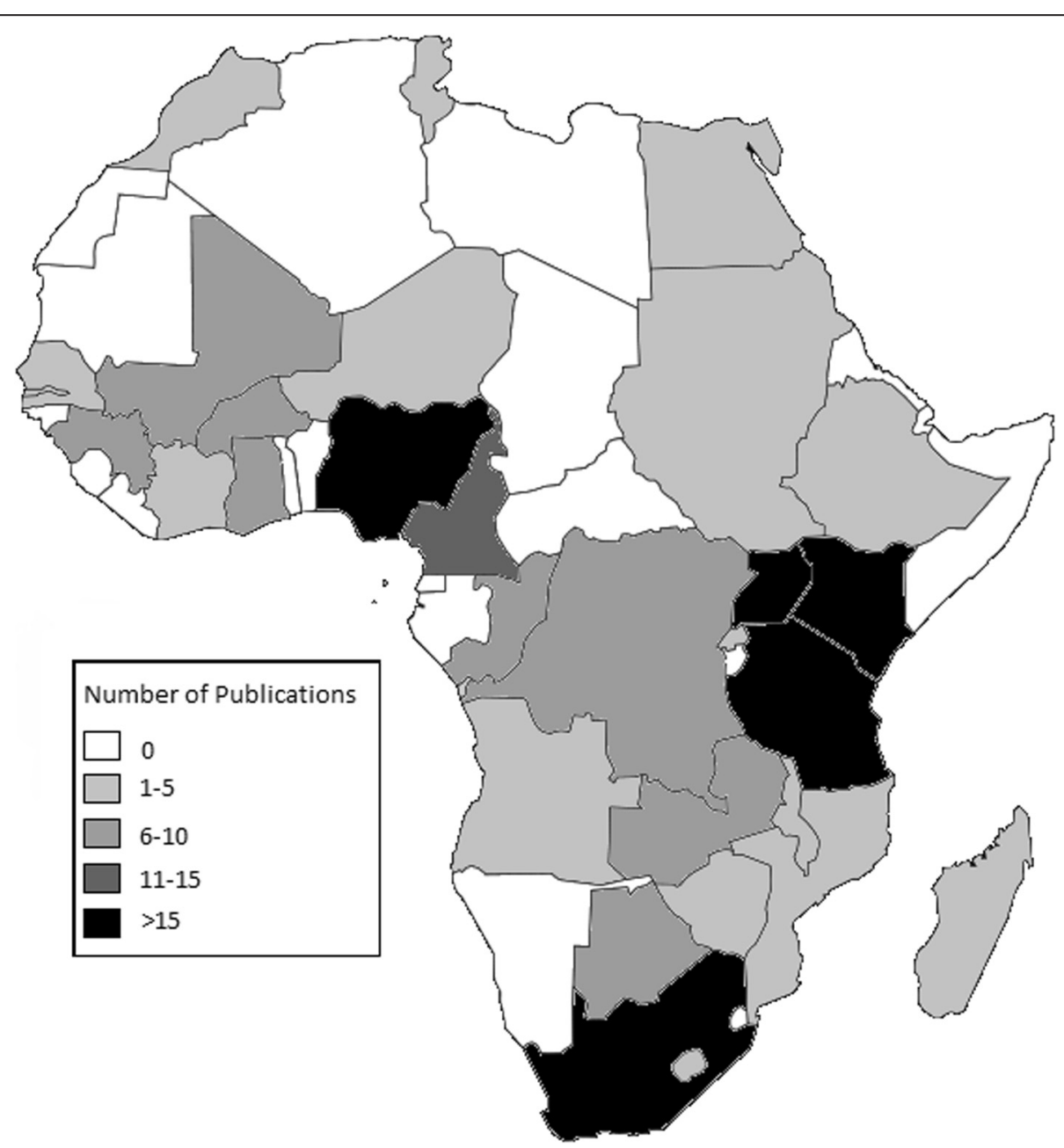

Fig. 2 Geographic Distribution of Cervical Cancer Research within Africa. Figure 2 is a map of Africa illustrating the geographic distribution of cervical cancer research. The map represents individual countries only and does not clearly illustrate some of the smaller African countries. Fifty articles reporting on a geographic region were excluded (Excluded articles reported on the following geographic regions: Middle East/North Africa (2); 3 GAVI-eligible countries (3); Global (6); LMIC countries/developing countries (14); Africa/Sub-Saharan Africa (25). Image modified from: Tourbillon (Own work) [Public domain], via Wikimedia Commons, available at https://commons.wikimedia.org/wiki/File:Colored_map_of_Africa.png\# 
publications with a regional focus. Five categories ranging from 0 to $>15$ publications are delineated by a color gradient per country.

South Africa had the highest number of cervical cancer publications included in this review $(n=85)$, followed by Nigeria $(n=61)$, and Uganda and Kenya, with 33 and 32 publications, respectively. These same four countries also have cervical cancer publications representing each of the four target categories: primary, secondary, tertiary prevention and quality of life. Botswana, Cote d'Ivoire, Malawi and Morocco had publications from each of the three types of prevention, but none related to quality of life. Eligible cervical cancer publications were missing from a total of 24 African countries, including: Algeria, Benin, Burundi, Cape Verde, Central African Republic, Chad, Comoros, Djibouti, Equatorial Guinea, Eritrea, Gabon, Guinea-Bissau, Liberia, Libya, Mauritania, Mauritius, Namibia, Sao Tome and Principe, Seychelles, Sierra Leone, Somalia, South Sudan, Swaziland, and Togo.

\section{Discussion}

This study reviewed cervical cancer related research from countries in Africa over the past decade and categorized them according to primary focus areas within public health. Among a total of 380 research articles/reports eligible for inclusion in this systematic review, the majority ( $54.6 \%$ ) focused on secondary prevention. The number of publication focusing on primary prevention (23.4 \%), particularly HPV vaccination, increased significantly in the past decade. Research regarding the treatment of precancerous lesions and invasive cervical cancer are emerging (17.6\%), but infrastructure and feasibility challenges in many countries have impeded efforts to provide and evaluate such treatment services. Studies assessing varying aspects of quality of life among women living with cervical cancer are limited, representing only $4.1 \%$ of eligible publications. Across all categories, $11.3 \%$ of publications focused on cervical cancer prevention or treatment among HIV-infected women. While integrated throughout, $n=65(17.1 \%)$ publications focused on various aspects of feasibility for cervical cancer control efforts, appealing for increased financial, human and political investments to adequately address the existing and increasing need for cervical cancer prevention and treatment services.

\section{Limitations}

While a wide range of articles are referenced in the introduction of this manuscript, the results section of the review excludes a significant number of articles describing the epidemiology of cervical cancer in sub Saharan Africa or a focus on genetic biomarkers, which were beyond the scope of this review. Some publications had significant overlap in the topics presented. This was particularly true for findings on secondary and tertiary prevention. For the purpose of this review, publications were assigned to only one category, but this does not mean other articles or reports did not give a degree of focus to additional categories as well.

\section{Conclusion}

The number of publications focused on cervical cancer control and treatment in African countries has increased over the past decade. Tertiary prevention (i.e. treatment of disease with effective medicine) and quality of life of cervical cancer survivors are two under-researched areas in African countries. Similarly, there are several countries in Africa with little to no research ever conducted on cervical cancer. Given the significant burden and high morbidity and mortality experienced by women with cervical cancer in this setting, targeted research is critically needed, particularly implementation science research to inform feasible and sustainable strategies to maximize the number of women reached with services. Lessons learned reports and publications describing and evaluating service implementation are highly relevant, as are cost-effectiveness studies to guide service strategies for scale-up. There is a need to support national capacity for developing population-based cancer registries to track cases and project needs [255], strategies to increase the availability of cervical cancer screening and treatment, and innovative strategies to retain cervical cancer patient in treatment.

\section{Abbreviations}

AFCRN, African Cancer Registry Network; AIDS, autoimmune deficiency syndrome; AIM, African index medicus; AORTIC, African Organization for Research and Training Center; CIN, cervical intraepithelial neoplasia; DALY, daily adjusted life years; DNA, deoxyribonucleic acid; GAVI, global alliance for vaccines and immunizations; HIV, human immunodeficiency virus; HPV, human papilloma virus; LEEP, loop electrical excision procedure; LEETZ, large loop excision of the transformation zone; LMIC, low and middle income countries; NCBI, National Center for Biotechnology Information; SSA, Sub Saharan Africa; VIA, visual inspection with acetic acid; VILI, visual inspection with lugol's iodine; WHO, World Health Organization

\section{Acknowledgements}

Not applicable.

\section{Funding}

This systematic review was not directly funded; however, effort for authors SFK and CW was partially funded by R01HD076673.

\section{Availability of data and materials}

Data used for this study is limited to previously published or presented cervical cancer research and, thus, is publicly available by journal and conference review.

\section{Authors' contributions}

SFK conceived of the idea for the systematic review, outlined the results and wrote the Introduction and Methods. CW, MM, NM and FNM systematically reviewed and summarized research meeting the eligibility criteria. MM and EB provided technical review and quality assurance given their clinical expertise in cervical cancer screening and treatment in low resource settings. CW compiled the extensive list of citations. All authors contributed to drafting and reviewing of the final manuscript. All authors read and approved the final manuscript. 


\section{Authors' information}

Not applicable.

\section{Competing interests}

The authors declare that they have no competing interests.

\section{Consent for publication}

Not applicable.

\section{Ethics approval and consent to participate}

This systematic review did not require approval from an ethical review board or informed consent with participants as research efforts were limited to the review and analysis of previously published or presented cervical cancer research in African countries.

\section{Author details}

'Department of Family Medicine, University of Kansas Medical Center, Kansas City, USA. ${ }^{2}$ Family AIDS Care and Education Services, Kenya Medical Research Institute, Kisumu, Kenya. ${ }^{3}$ Department of Preventive Medicine and Public Health, University of Kansas Medical Center, Kansas City, USA. ${ }^{4}$ Cente for Microbiology Research, Kenya Medical Research Institute, Nairobi, Kenya. ${ }^{5}$ Department of Obstetrics and Gynecology, University of Nairobi, Nairobi, Kenya.

\section{Received: 21 November 2015 Accepted: 21 May 2016}

\section{Published online: 04 June 2016}

\section{References}

1. Globocan. Cervical Cancer: Estimated Incidence, Mortality and Prevalence Worldwide in 2012 [Internet]. International Agency for Research on Cancer (IARC) 2012. Available from: http:/globocan.iarc.fr/old/FactSheets/cancers/cervix-new.asp. Accessed 6 July 2015.

2. Frisch M. Human Papillomavirus-Associated Cancers in Patients With Human Immunodeficiency Virus Infection and Acquired Immunodeficiency Syndrome. J Natl Cancer Inst. 2000;92(18):1500-10.

3. Hawes SE, Critchlow CW, Faye Niang MA, Diouf MB, Diop A, Touré $P$, et al. Increased Risk of High-Grade Cervical Squamous Intraepithelial Lesions and Invasive Cervical Cancer among African Women with Human Immunodeficiency Virus Type 1 and 2 Infections. J Infect Dis. 2003:188(4):555-63.

4. Hawes SE, Critchlow CW, Sow PS, Touré P, N'Doye I, Diop A, et al. Incident high-grade squamous intraepithelial lesions in Senegalese women with and without human immunodeficiency virus type 1 (HIV-1) and HIV-2. J Natl Cancer Inst. 2006;98(2):100-9.

5. Clarke B, Chetty R. Postmodern cancer: the role of human immunodeficiency virus in uterine cervical cancer. Mol Pathol MP. 2002;55(1):19-24

6. Maiman M, Fruchter RG, Serur E, Remy JC, Feuer G, Boyce J. Human immunodeficiency virus infection and cervical neoplasia. Gynecol Oncol. 1990:38(3):377-82

7. Petry KU, Scheffel D, Bode U, Gabrysiak T, Köchel H, Kupsch E, et al. Cellula immunodeficiency enhances the progression of human papillomavirusassociated cervical lesions. Int J Cancer J Int Cancer. 1994;57(6):836-40.

8. Centers for Disease Control and Prevention; National Center for Infectious Diseases Division of HIV/AIDS. 1993 Revised Classification System for HIV Infection and Expanded Surveillance Case Definition for AIDS Among Adolescents and Adults [Internet]. [cited 2014 Dec 12]. Available from: http:// www.cdc.gov/mmwr/preview/mmwrhtml/00018871.htm. Accessed 6 July 2015

9. World Health Organization (WHO). Comprehensive cervical cancer prevention and control: a healthier future for girls and women [Internet]. 2013. Available from: http://apps.who.int/iris/bitstream/10665/78128/3/ 9789241505147_eng.pdf?ua=1. Accessed 6 July 2015.

10. de Freitas AC, Coimbra EC, Leitão Mda CG. Molecular targets of HPV oncoproteins: potential biomarkers for cervical carcinogenesis. Biochim Biophys Acta. 2014;1845(2):91-103.

11. Flepisi BT, Bouic P, Sissolak G, Rosenkranz B. Biomarkers of HIV-associated Cancer. Biomark Cancer. 2014;3:11-20.

12. Cunningham MS, Davison C, Aronson KJ. HPV vaccine acceptability in Africa: a systematic review. Prev Med. 2014;69:274-9.

13. Hopkins TG, Wood N. Female human papillomavirus (HPV) vaccination: Global uptake and the impact of attitudes. Vaccine. 2013;31(13):1673-9.

14. Levin A, Wang SA, Levin C, Tsu V, Hutubessy R. Costs of Introducing and Delivering HPV Vaccines in Low and Lower Middle Income Countries: Inputs for GAVI Policy on Introduction Grant Support to Countries. PLoS ONE. 2014 9(6):e101114. Metcalfe JZ, editor.
15. Perlman S, Wamai RG, Bain PA, Welty T, Welty E, Ogembo JG. Knowledge and Awareness of HPV Vaccine and Acceptability to Vaccinate in Sub-Saharan Africa: A Systematic Review. PLoS ONE. 2014;9(3):e90912. Hozbor DF, editor.

16. Anorlu Rl, Ola ER, Abudu OO. Low cost methods for secondary prevention of cervical cancer in developing countries. Niger Postgrad Med J. 2007;14(3):242-6.

17. Boisen M, Diedrich JT, Lonky NM, Guido R. Secondary prevention of cervical cancer part 1: screening for cervical cancer and its precursors. Clin Obstet Gynecol. 2014;57(2):279-91.

18. Guido R. Secondary prevention of cervical cancer part 2: initial management of abnormal cervical cancer screening test. Clin Obstet Gynecol. 2014;57(2):292-301.

19. Guido R, Lonky NM, Diedrich J. Secondary prevention of cervical cancer part 3: evidence-based management of women with cervical intraepithelial neoplasia. Clin Obstet Gynecol. 2014;57(2):302-15.

20. Roque DR, Wysham WZ, Soper JT. The surgical management of cervical cancer: an overview and literature review. Obstet Gynecol Surv. 2014:69(7):426-41.

21. Walboomers JM, Jacobs MV, Manos MM, Bosch FX, Kummer JA, Shah KV, et al. Human papillomavirus is a necessary cause of invasive cervical cancer worldwide. J Pathol. 1999;189(1):12-9.

22. Clifford GM, Smith JS, Plummer M, Muñoz N, Franceschi S. Human papillomavirus types in invasive cervical cancer worldwide: a meta-analysis. Br J Cancer. 2003:88(1):63-73.

23. Li N, Franceschi S, Howell-Jones R, Snijders PJF, Clifford GM. Human papillomavirus type distribution in 30,848 invasive cervical cancers worldwide: Variation by geographical region, histological type and year of publication. Int J Cancer. 2011;128(4):927-35.

24. WHO. Human papillomavirus laboratory manual [Internet]. Geneva, Switzerland; 2010. Available from: http://whqlibdoc.who.int/hq/2010/WHO_ IVB_10.12_eng.pdf?ua=1. Accessed 6 July 2015.

25. Centers for Disease Control and Prevention (CDC). HPV Vaccine Information for Clinicians - Fact Sheet [Internet]. 2012 [cited 2014 Dec 17]. Available from: http:// www.cdc.gov/std/hpv/stdfact-hpv-vaccine-hcp.htm. Accessed 6 July 2015.

26. for the HPV PATRICIA Study Group, Castellsagué X, Paavonen J, Jaisamrarn $U$, Wheeler CM, Skinner SR, et al. Risk of first cervical HPV infection and precancerous lesions after onset of sexual activity: analysis of women in the control arm of the randomized, controlled PATRICIA trial. BMC Infect Dis [Internet]. 2014 [cited 2014 Dec 16];14(1). Available from: http://www. biomedcentral.com/1471-2334/14/551. Accessed 6 July 2015.

27. Collins S, Mazloomzadeh S, Winter H, Blomfield P, Bailey A, Young LS, et al. High incidence of cervical human papillomavirus infection in women during their first sexual relationship. BJOG Int J Obstet Gynaecol. 2002;109(1):96-8.

28. Kjaer SK, Chackerian B, van den Brule AJ, Svare El, Paull G, Walbomers JM, et al. High-risk human papillomavirus is sexually transmitted: evidence from a follow-up study of virgins starting sexual activity (intercourse). Cancer Epidemiol Biomark Prev Publ Am Assoc Cancer Res Cosponsored Am Soc Prev Oncol. 2001:10(2):101-6.

29. Garland SM, Hernandez-Avila M, Wheeler CM, Perez G, Harper DM, Leodolter S, et al. Quadrivalent Vaccine against Human Papillomavirus to Prevent Anogenital Diseases. N Engl J Med. 2007;356(19):1928-43.

30. The Future II Study Group. Quadrivalent Vaccine against Human Papillomavirus to Prevent High-Grade Cervical Lesions. N Engl J Med. 2007;356(19):1915-27.

31. World Health Organization (WHO). Human papillomavirus vaccines: WHO position paper, October 2014 [Internet]. 2014. Available from: http://www. who.int/wer/2014/wer8943.pdf?ua=1. Accessed 6 July 2015.

32. Dobson SRM, McNeil S, Dionne M, Dawar M, Ogilvie G, Krajden M, et al. Immunogenicity of 2 doses of HPV vaccine in younger adolescents vs 3 doses in young women: a randomized clinical trial. JAMA. 2013;309(17):1793-802.

33. Kreimer AR, Rodriguez AC, Hildesheim A, Herrero R, Porras C, Schiffman M, et al. Proof-of-Principle Evaluation of the Efficacy of Fewer Than Three Doses of a Bivalent HPV16/18 Vaccine. JNCI J Natl Cancer Inst. 2011;103(19):1444-51.

34. Romanowski B, Schwarz TF, Ferguson LM, Ferguson M, Peters K, Dionne M, et al. Immune response to the HPV-16/18 AS04-adjuvanted vaccine administered as a 2-dose or 3-dose schedule up to 4 years after vaccination: results from a randomized study. Hum Vaccines Immunother. 2014;10(5):1155-65.

35. World Health Organization. Evidence based recommendations on Human Papilloma Virus (HPV) Vaccines Schedules [Internet]. 2014. Available from: http://www.who.int/immunization/sage/meetings/2014/april/1_HPV Evidence_based_recommendationsWHO_with_Appendices2_3.pdf. Accessed 6 July 2015.

36. Cervical Cancer Action. Cervical Cancer Action 2007 to 2014 [Internet]. 2014 Available from: http://www.cervicalcanceraction.org/pubs/CCA_ accomplishments_2007-2014.pdf. Accessed 6 July 2015. 
37. Cagney H. GAVI to fund HPV vaccines in low-income countries. Lancet Oncol. 2013;14(3):e92.

38. HPV Subteam, Gavi Alliance. HPV Demonstration Programme Update and initial lessons learnt on programme design. GAVI Alliance Board Technical Briefing Session. 2014. Geneva, Switzerland.

39. Friedman AL, Oruko KO, Habel MA, Ford J, Kinsey J, Odhiambo F, et al Preparing for human papillomavirus vaccine introduction in Kenya: implications from focus-group and interview discussions with caregivers and opinion leaders in Western Kenya. BMC Public Health. 2014;14:855.

40. Katahoire RA, Jitta J, Kivumbi G, Murokora D, Arube WJ, Siu G, et al. An assessment of the readiness for introduction of the HPV vaccine in Uganda. Afr J Reprod Health. 2008;12(3):159-72.

41. Ports KA, Reddy DM, Rameshbabu A. Barriers and Facilitators to HPV Vaccination: Perspectives from Malawian Women. Women Health. 2013;53(6):630-45.

42. Wigle J, Coast E, Watson-Jones D. Human papillomavirus (HPV) vaccine implementation in low and middle-income countries (LMICS): Health system experiences and prospects. Vaccine. 2013;31(37):3811-7.

43. Ladner J, Besson M-H, Hampshire R, Tapert L, Chirenje M, Saba J. Assessment of eight HPV vaccination programs implemented in lowest income countries. BMC Public Health. 2012;12(1):370.

44. Stanley M. HPV vaccination in boys and men. Hum Vaccines Immunother. 2014;10(7):2109-11.

45. Plummer M, Franceschi S. Strategies for HPV prevention. Virus Res. 2002; 89(2):285-93.

46. Auvert B, Sobngwi-Tambekou J, Cutler E, Nieuwoudt M, Lissouba P, Puren A, et al. Effect of Male Circumcision on the Prevalence of High-Risk Human Papillomavirus in Young Men: Results of a Randomized Controlled Trial Conducted in Orange Farm, South Africa. J Infect Dis. 2009;199(1):14-9.

47. Serwadda D, Wawer MJ, Makumbi F, Kong X, Kigozi G, Gravitt P, et al. Circumcision of HIV-Infected Men: Effects on High-Risk Human Papillomavirus Infections in a Randomized Trial in Rakai, Uganda. J Infect Dis. 2010;201(10):1463-9.

48. Tobian AAR, Serwadda D, Quinn TC, Kigozi G, Gravitt PE, Laeyendecker O, et al. Male Circumcision for the Prevention of HSV-2 and HPV Infections and Syphilis. N Engl J Med. 2009;360(13):1298-309.

49. Sankaranarayanan R, Budukh AM, Rajkumar R. Effective screening programmes for cervical cancer in low- and middle-income developing countries. Bull World Health Organ. 2001;79(10):954-62.

50. Sahasrabuddhe W, Parham GP, Mwanahamuntu MH, Vermund SH. Cervical cancer prevention in low- and middle-income countries: feasible, affordable, essential. Cancer Prev Res Phila Pa. 2012;5(1):11-7.

51. World Health Organization. WHO guidelines for screening and treatment of precancerous lesions for cervical cancer prevention. [Internet]. 2013 [cited 2015 Jan 7]. Available from: http://www.ncbi.nlm.nih.gov/books/ NBK195239/. Accessed 6 July 2015.

52. Gakidou E, Nordhagen S, Obermeyer Z. Coverage of cervical cancer screening in 57 countries: low average levels and large inequalities. PLoS Med. 2008;5(6):e132.

53. Ports KA, Reddy DM, Rameshbabu A. Cervical Cancer Prevention in Malawi: A Qualitative Study of Women's Perspectives. J Health Commun. 2015;20(1):97-104.

54. Denny L, Quinn M, Sankaranarayanan R. Chapter 8: Screening for cervical cancer in developing countries. Vaccine. 2006;24 Suppl 3:S3/71-7.

55. Huchko M, Sneden J, Leslie HH, Abdulrahim N, Maloba M, Bukusi E, et al. A comparison of two visual inspection methods for cervical cancer screening among HIV-infected women in Kenya. Bull World Health Organ. 2014;92(3):195-203.

56. Huchko MJ, Sneden J, Sawaya G, Smith-McCune K, Maloba M, Abdulrahim $\mathrm{N}$, et al. Accuracy of visual inspection with acetic acid to detect cervical cancer precursors among HIV-infected women in Kenya. Int J Cancer J Int Cancer. 2015;136(2):392-8

57. Jacob M, Broekhuizen FF, Castro W, Sellors J. Experience using cryotherapy for treatment of cervical precancerous lesions in low-resource settings. Int J Gynaecol Obstet Off Organ Int Fed Gynaecol Obstet. 2005;89 Suppl 2:S13-20.

58. Gaffikin L, Blumenthal PD, Emerson M, Limpaphayom K, Royal Thai College of Obstetricians and Gynaecologists (RTCOG)/JHPIEGO Corporation Cervical Cancer Prevention Group [corrected]. Safety, acceptability, and feasibility of a single-visit approach to cervical-cancer prevention in rural Thailand: a demonstration project. Lancet Lond Engl. 2003;361(9360):814-20.

59. Goldie SJ, Gaffikin L, Goldhaber-Fiebert JD, Gordillo-Tobar A, Levin C, Mahé $\mathrm{C}$, et al. Cost-effectiveness of cervical-cancer screening in five developing countries. N Engl J Med. 2005;353(20):2158-68.
60. Blumenthal PD, Lauterbach M, Sellors JW, Sankaranarayanan R. Training for cervical cancer prevention programs in low-resource settings: focus on visual inspection with acetic acid and cryotherapy. Int J Gynaecol Obstet Off Organ Int Fed Gynaecol Obstet. 2005;89 Suppl 2:S30-7.

61. Khozaim K, Orang'o E, Christoffersen-Deb A, Itsura P, Oguda J, Muliro H, et al. Successes and challenges of establishing a cervical cancer screening and treatment program in western Kenya. Int J Gynaecol Obstet Off Organ Int Fed Gynaecol Obstet. 2014;124(1):12-8.

62. Perng P, Perng W, Ngoma T, Kahesa C, Mwaiselage J, Merajver SD, et al. Promoters of and barriers to cervical cancer screening in a rural setting in Tanzania. Int J Gynaecol Obstet Off Organ Int Fed Gynaecol Obstet. 2013;123(3):221-5.

63. Blumenthal PD, Gaffikin L, Deganus S, Lewis R, Emerson M, Adadevoh S. Cervical cancer prevention: safety, acceptability, and feasibility of a single-visit approach in Accra, Ghana. Am J Obstet Gynecol. 2007;196(4):407. e1-407.e9.

64. Castro W, Gage J, Gaffikin L, Sellors J, Sherris J. Effectiveness, Safety, and Acceptability of Cryotherapy: A Systematic Literature Review. [Internet]. Seattle: Path; 2003. Available from: http://www.path.org/publications/detail.php?i=687. Accessed 6 July 2015.

65. Apgar BS, Kaufman AJ, Bettcher C, Parker-Featherstone E. Gynecologic procedures: colposcopy, treatments for cervical intraepithelial neoplasia and endometrial assessment. Am Fam Physician. 2013;87(12):836-43.

66. Muruka K, Nelly MR, Gichuhi W, Anne-Beatrice K, Eunice CJ, Rose KJ. Same day colposcopic examination and loop electrosurgical excision procedure (LEEP) presents minimal overtreatment and averts delay in treatment of cervical intraepithelial neoplasia in Kenyatta National Hospital, Kenya. Open J Obstet Gynecol. 2013;03(03):313-8.

67. U.S. Preventive Services Task Force. ervical Cancer Screening: Summary of Recommendations and Evidence [Internet]. 2012. Available from: http:// www.uspreventiveservicestaskforce.org/Page/Topic/recommendationsummary/cervical-cancer-screening. Accessed 6 July 2015.

68. World Health Organization (WHO). Comprehensive Cervical Cancer Control: A guide to essential practice - Second edition [Internet]. 2014. Available from: http://apps.who.int/iris/bitstream/10665/144785/1/9789241548953_eng.pdf. Accessed 6 July 2015.

69. Sherris J, Wittet S, Kleine A, Sellors J, Luciani S, Sankaranarayanan R, et al. Evidence-Based, Alternative Cervical Cancer Screening Approaches in LowResource Settings. Int Perspect Sex Reprod Health. 2009;35(03):147-54.

70. Abotchie PN, Shokar NK. Cervical Cancer Screening Among College Students in Ghana: Knowledge and Health Beliefs. Int J Gynecol Cancer. 2009;19(3):412-6.

71. Maree JE, Lu XM, Wright SCD. Combining breast and cervical screening in an attempt to increase cervical screening uptake. An intervention study in a South African context: Cervical screening uptake. Eur J Cancer Care (Engl). 2012;21(1):78-86.

72. Mingo AM, Panozzo CA, DiAngi YT, Smith JS, Steenhoff AP, RamogolaMasire D, et al. Cervical cancer awareness and screening in Botswana. Int J Gynecol Cancer Off J Int Gynecol Cancer Soc. 2012;22(4):638-44.

73. Mupepi SC, Sampselle CM, Johnson TRB. Knowledge, attitudes, and demographic factors influencing cervical cancer screening behavior of Zimbabwean women. J Womens Health. 2002;20(6):943-52.

74. Tebeu P-M, Major AL, Rapiti E, Petignat P, Bouchardy C, Sando Z, et al. The attitude and knowledge of cervical cancer by Cameroonian women; a clinical survey conducted in Maroua, the capital of Far North Province of Cameroon. Int J Gynecol Cancer Off J Int Gynecol Cancer Soc. 2008;18(4):761-5.

75. Ezechi OC, Gab-Okafor CV, Ostergren PO, Odberg PK. Willingness and acceptability of cervical cancer screening among HIV positive Nigerian women. BMC Public Health. 2013;13(1):46.

76. Rosser Jl, Njoroge B, Huchko MJ. Cervical Cancer Screening Knowledge and Behavior among Women Attending an Urban HIV Clinic in Western Kenya. J Cancer Educ [Internet]. 2015 [cited 2015 Mar 12]; Available from: http://link. springer.com/10.1007/s13187-014-0787-7. Accessed 6 July 2015.

77. Plotkin M, Besana GV, Yuma S, Kim Y, Kulindwa Y, Kabole F, et al. Integrating HIV testing into cervical cancer screening in Tanzania: an analysis of routine service delivery statistics. BMC Womens Health. 2014;14(1):120.

78. Ayinde OA, Omigbodun AO, llesanmi AO. Awareness of cervical cancer, Papanicolaou's smear and its utilisation among female undergraduates in Ibadan. Afr J Reprod Health. 2004:8(3):68-80.

79. Eze JN, Umeora OU, Obuna JA, Egwuatu VE, Ejikeme BN. Cervical cancer awareness and cervical screening uptake at the Mater Misericordiae Hospital, Afikpo, Southeast Nigeria. Ann Afr Med. 2012;11(4):238-43. 
80. Hoque M. Cervical Cancer Awareness and Preventive Behaviour among Female University Students in South Africa. Asian Pac J Cancer Prev. 2010;11:127-30.

81. Kivuti-Bitok LW, Pokhariyal GP, Abdul R, McDonnell G. An exploration of opportunities and challenges facing cervical cancer managers in Kenya. BMC Res Notes. 2013;6(1):136.

82. Asonganyi E, Vaghasia M, Rodrigues C, Phadtare A, Ford A, Pietrobon R, et al. Factors affecting compliance with clinical practice guidelines for pap smear screening among healthcare providers in africa: systematic review and meta-summary of 2045 individuals. PLOS ONE. 2013;8(9):e72712.

83. Awodele O, Adeyomoye AA, Awodele DF, Kwashi V, Awodele IO, Dolapo DC. A study on cervical cancer screening amongst nurses in Lagos University Teaching Hospital, Lagos, Nigeria. J Cancer Educ Off J Am Assoc Cancer Educ. 2011;26(3):497-504

84. Odafe S, Torpey K, Khamofu H, Oladele E, Adedokun O, Chabikuli O, et al. Integrating cervical cancer screening with HIV care in a district hospital in Abuja, Nigeria. Niger Med J J Niger Med Assoc. 2013;54(3):176-84.

85. Wright TC, Kuhn L. Alternative approaches to cervical cancer screening for developing countries. Best Pract Res Clin Obstet Gynaecol. 2012;26(2):197-208.

86. Crum CP, Abbott DW, Quade BJ. Cervical cancer screening: from the Papanicolaou smear to the vaccine era. J Clin Oncol Off J Am Soc Clin Oncol. 2003;21(10 Suppl):224s-30.

87. Maranga IO, Hampson L, Oliver AW, Gamal A, Gichangi P, Opiyo A, et al. Analysis of Factors Contributing to the Low Survival of Cervical Cancer Patients Undergoing Radiotherapy in Kenya. PLoS ONE. 2013;8(10):e78411. Hawkins SM, editor.

88. Mosha D, Mahande M, Ahaz J, Njau B, Kitali B, Obure J. Factors associated with management of cervical cancer patients at KCMC Hospital, Tanzania: a retrospective cross-sectional study. Tanzan J Health Res [Internet]. 2009;11(2). Available from: http://www.ajol.info/index.php/thrb/article/view/45204/28692. Accessed 6 July 2015

89. Gaya S, Muhammad A, Yakasai I, Galadanci H, Garba I. Cancer of the cervix in unscreened West African women. J Basic Clin Reprod Sci. 2012;1(1):44.

90. Chirenje ZM, Rusakaniko S, Akino V, Mlingo M. A review of cervical cancer patients presenting in Harare and Parirenyatwa Hospitals in 1998. Cent Afr J Med. 2000;46(10):264-7.

91. International Agency for Research on Cancer, World Health Organization. Cervical Cancer Screening [Internet]. 2005. Available from: http://www.iarc.fr/ en/publications/pdfs-online/prev/handbook10/HANDBOOK10.pdf. Accessed 6 July 2015.

92. Southern Africa Litigation Centre. Tackling Cervical Cancer: Improving Access to Cervical Cancer Services for Women in Southern Africa [Internet]. 2012 [cited 2015 May 14]. Available from: http://www.southernafricalitigationcentre org/1/wp-content/uploads/2012/11/CERVICAL-CANCER-Report1.pdf. Accessed 6 July 2015.

93. Abu-Rustum NR, Sonoda Y. Fertility-sparing surgery in early-stage cervical cancer: indications and applications. J Natl Compr Cancer Netw JNCCN. 2010;8(12):1435-8.

94. World Health Organization. Cervical Cancer - Issues and Challenges [Internet]. 2015. Available from: http://www.afro.who.int/en/clusters-aprogrammes/dpc/non-communicable-diseases-managementndm/ programme-components/cancer/cervical-cancer/2813-cervical-cancer-issuesand-challenges.html. Accessed 6 July 2015.

95. Chokunonga E, Ramanakumar AV, Nyakabau AM, Borok MZ, Chirenje ZM, Sankila R, et al. Survival of cervix cancer patients in Harare, Zimbabwe, 1995-1997. Int J Cancer J Int Cancer. 2004;109(2):274-7.

96. Wabinga H, Ramanakumar AV, Banura C, Luwaga A, Nambooze S, Parkin DM. Survival of cervix cancer patients in Kampala, Uganda: 1995-1997. Br J Cancer. 2003:89(1):65-9.

97. Ferlay J, Soerjomataram I, Dikshit R, Eser S, Mathers C, Rebelo M, et al. Cancer incidence and mortality worldwide: Sources, methods and major patterns in GLOBOCAN 2012: Globocan 2012. Int J Cancer. 2015;136(5):E359-86.

98. Arbyn M, Castellsague X, de Sanjose S, Bruni L, Saraiya M, Bray F, et al. Worldwide burden of cervical cancer in 2008. Ann Oncol. 2011;22(12):2675-86.

99. Allemani C, Weir HK, Carreira H, Harewood R, Spika D, Wang X-S, et al. Global surveillance of cancer survival 1995-2009: analysis of individual data for 25676887 patients from 279 population-based registries in 67 countries (CONCORD-2). Lancet. 2015;385(9972):977-1010.

100. Kantelhardt EJ, Moelle U, Begoinn M, Addissie A, Trocchi P, Yonas B, et al. Cervical cancer in Ethiopia: survival of 1,059 patients who received oncologic therapy. Oncologist. 2014;19(7):727-34.

101. Nuhu FT, Adebayo KO, Adejumo O. Quality of life of people with cancers in Ibadan, Nigeria. J Ment Health Abingdon Engl. 2013;22(4):325-33.
102. Vistad I, Fosså SD, Dahl AA. A critical review of patient-rated quality of life studies of long-term survivors of cervical cancer. Gynecol Oncol. 2006;102(3):563-72.

103. Soerjomataram I, Lortet-Tieulent J, Parkin DM, Ferlay J, Mathers C, Forman D, et al. Global burden of cancer in 2008: a systematic analysis of disability-adjusted life-years in 12 world regions. Lancet. 2012; 380(9856):1840-50.

104. Kamau RK, Osoti AO, Njuguna EM. Effect of diagnosis and treatment of inoperable cervical cancer on quality of life among women receiving radiotherapy at Kenyatta National Hospital. East Afr Med J. 2007;84(1):24-30.

105. Pfaendler KS, Wenzel L, Mechanic MB, Penner KR. Cervical cancer survivorship: long-term quality of life and social support. Clin Ther. 2015;37(1):39-48.

106. Abayomi J, Kirwan J, Hackett A, Bagnall G. A study to investigate women's experiences of radiation enteritis following radiotherapy for cervical cancer. J Hum Nutr Diet Off J Br Diet Assoc. 2005;18(5):353-63.

107. Adewuyi SA, Shittu OS, Rafindadi AH, Zayyan MS, Samaila MOA, Oguntayo AO. Cisplatin chemotherapy for haemostasis in bleeding cervical cancer: experience from a resource-poor setting. Niger Postgrad Med J. 2010;17(2):122-7.

108. Maree JE, Mosalo A, Wright SCD. "It depends on how the relationship was before you became ill": black South African women's experiences of life partner support through the trajectory of cervical cancer. Eur J Cancer Care (Engl). 2013;22(4):459-67.

109. Levin AO, Carpenter KM, Fowler JM, Brothers BM, Andersen BL, Maxwell GL. Sexual morbidity associated with poorer psychological adjustment among gynecological cancer survivors. Int J Gynecol Cancer Off J Int Gynecol Cancer Soc. 2010;20(3):461-70.

110. Herzog TJ, Wright JD. The impact of cervical cancer on quality of life-the components and means for management. Gynecol Oncol. 2007;107(3):572-7.

111. Ye S, Yang J, Cao D, Zhu L, Lang J, Shen K. Quality of life and sexual function of cervical cancer patients following radical hysterectomy and vaginal extension. Zhonghua Fu Chan Ke Za Zhi. 2014;49(8):609-15.

112. Eftekhar M, Pourmasumi S, Karimi-Zarchi M. Preservation of ovarian function during chemotherapy and radiotherapy in young women with malignancies. Iran J Reprod Med. 2014;12(6):377-82.

113. Karimi Zarchi M, Mousavi A, Gilani MM, Barooti E, Amini Rad O, Ghaemmaghami F, et al. Fertility sparing treatments in young patients with gynecological cancers: Iranian experience and literature review. Asian Pac J Cancer Prev APJCP. 2011;12(8):1887-92.

114. Rodriguez-Wallberg KA, Oktay K. Options on fertility preservation in female cancer patients. Cancer Treat Rev. 2012;38(5):354-61.

115. Dyer SJ. Psychological distress among women suffering from couple infertility in South Africa: a quantitative assessment. Hum Reprod. 2005;20(7):1938-43.

116. Downing J, Powell RA, Mwangi-Powell F. Home-Based Palliative Care in subSaharan Africa. Home Healthc Nurse J Home Care Hosp Prof. 2010;28(5):298-307.

117. Cleary J, Powell RA, Munene G, Mwangi-Powell FN, Luyirika E, Kiyange F, et al. Formulary availability and regulatory barriers to accessibility of opioids for cancer pain in Africa: a report from the Global Opioid Policy Initiative (GOPI). Ann Oncol. 2013;24 suppl 11:xi14-23.

118. Nuhu FT, Odejide OA, Adebayo KO, Yusuf AJ. Psychological and physical effects of pain on cancer patients in Ibadan, Nigeria. Afr J Psychiatry. 2009;12(1):64-70.

119. Mwangi-Powell F, Dix O. Palliative care in Africa: an overview. Afr Health [Internet]. 2011. Available from: http://www.ipcrc.net/pdfs/Palliative-careAfrica-Health-Article.pdf. Accessed 6 July 2015.

120. AFCRN. AFCRN: African Cancer Registry Network [Internet]. 2015 [cited 2015 Mar 11]. Available from: http://www.afcrn.org/. Accessed 6 July 2015.

121. Morhason-Bello IO, Odedina F, Rebbeck TR, Harford J, Dangou J-M, Denny L, et al. Challenges and opportunities in cancer control in Africa: a perspective from the African Organisation for Research and Training in Cancer. Lancet Oncol. 2013;14(4):e142-51.

122. Busolo DS, Woodgate RL. Cancer prevention in Africa: a review of the literature. Glob Health Promot. 2014;22:31-9.

123. Denny L, Wright T. Strategies for Overcoming the Barriers to Cervical Cancer Screening in Low-Resource Settings. Glob Libr Womens Med [Internet]. 2009 [cited 2015 Jul 8]; Available from: http://www.glowm.com/index. html?p=glowm.cml/section_view\&articleid=22. Accessed 6 July 2015.

124. Bingham A, Bishop A, Coffey P, Winkler J, Bradley J, Dzuba I, et al. Factors affecting utilization of cervical cancer prevention services in low-resource settings. Salud Pública México. 2003:45:408-16.

125. Mvundura M, Tsu V. Estimating the costs of cervical cancer screening in high-burden Sub-Saharan African countries. Int J Gynaecol Obstet Off Organ Int Fed Gynaecol Obstet. 2014;126(2):151-5. 
126. Remes $P$, Selestine V, Changalucha J, Ross DA, Wight D, de Sanjosé $S$, et al. A qualitative study of HPV vaccine acceptability among health workers, teachers, parents, female pupils, and religious leaders in northwest Tanzania. Vaccine. 2012;30(36):5363-7.

127. Bingham A, Drake JK, LaMontagne DS. Sociocultural Issues in the Introduction of Human Papillomavirus Vaccine in Low-Resource Settings. Arch Pediatr Adolesc Med. 2009;163(5):455.

128. Audu BM, Bukar M, Ibrahim Al, Swende TZ. Awareness and perception of human papilloma virus vaccine among healthcare professionals in Nigeria. J Obstet Gynaecol J Inst Obstet Gynaecol. 2014;12:1-4.

129. Hoque ME, Monokoane S, Van Hal G. Knowledge of and attitude towards human papillomavirus infection and vaccines among nurses at a tertiary hospital in South Africa. J Obstet Gynaecol. 2014;34(2):182-6.

130. Hoque ME, Ghuman S, Hal GV. Human Papillomavirus vaccination acceptability among female university students in South Africa. Asian Pac Cancer Prev APJCP. 2013;14(8):4865-9.

131. Makwe CC, Anorlu RI, Odeyemi KA. Human papillomavirus (HPV) infection and vaccines: knowledge, attitude and perception among female students at the University of Lagos, Lagos, Nigeria. J Epidemiol Glob Health. 2012;2(4):199-206.

132. Poole DN, Tracy JK, Levitz L, Rochas M, Sangare K, Yekta S, et al. A CrossSectional Study to Assess HPV Knowledge and HPV Vaccine Acceptability in Mali. PLoS ONE. 2013;8(2):e56402. Cameron DW, editor.

133. Wamai RG, Ayissi CA, Oduwo GO, Perlman S, Welty E, Welty T, et al. Awareness, knowledge and beliefs about HPV, cervical cancer and HPV vaccines among nurses in Cameroon: An exploratory study. Int J Nurs Stud. 2013;50(10):1399-406.

134. Ayissi CA, Wamai RG, Oduwo GO, Perlman S, Welty E, Welty T, et al. Awareness, Acceptability and Uptake of Human Papilloma Virus Vaccine Among Cameroonian School-Attending Female Adolescents. J Community Health. 2012;37(6):1127-35.

135. DiAngi YT, Panozzo CA, Ramogola-Masire D, Steenhoff AP, Brewer NT. A Cross-Sectional Study of HPV Vaccine Acceptability in Gaborone, Botswana. PLoS ONE. 2011;6(10):e25481. Grinsztejn BGJ, editor.

136. Coleman MA, Levison J, Sangi-Haghpeykar H. HPV vaccine acceptability in Ghana, West Africa. Vaccine. 2011:29(23):3945-50.

137. Iliyasu Z, Abubakar IS, Aliyu MH, Galadanci HS. Cervical cancer risk perception and predictors of human papilloma virus vaccine acceptance among female university students in northern Nigeria. J Obstet Gynaecol. 2010;30(8):857-62.

138. Muhwezi WW, Banura C, Turiho AK, Mirembe F. Parents' Knowledge, Risk Perception and Willingness to Allow Young Males to Receive Human Papillomavirus (HPV) Vaccines in Uganda. PLoS ONE. 2014;9(9):e106686.

139. Francis SA, Battle-Fisher M, Liverpool J, Hipple L, Mosavel M, Soogun S, et al. A qualitative analysis of South African women's knowledge, attitudes, and beliefs about HPV and cervical cancer prevention, vaccine awareness and acceptance, and maternal-child communication about sexual health. Vaccine. 2011;29(47):8760-5.

140. Morhason-Bello IO, Oladokun A, Adedokun B, Adesina O, Awolude O, Aimakhu C, et al. Introduction of human papilloma virus vaccine in a low resource setting: a survey of the views of Nigerian gynaecologists. Int J Gynecol Obstet. 2009;10752:S93-396.

141. Ugwu EO, Obi SN, Ezechukwu PC, Okafor II, Ugwu AO. Acceptability of human papilloma virus vaccine and cervical cancer screening among female healthcare workers in Enugu, Southeast Nigeria. Niger J Clin Pract. 2013;16(2):249-52.

142. Nelson JA, Francis SA, Liverpool J, Soogun S, Mofammere N. Healers in a nontraditional role; a focus group study of Sangoma's knowledge of and attitudes to cervical cancer prevention and screening in Johannesburg, South Africa. Sex Reprod Healthc Off J Swed Assoc Midwives. 2010;1 (4):195-6.

143. Makwe CC, Anorlu RI. Knowledge of and attitude toward human papillomavirus infection and vaccines among female nurses at a tertiary hospital in Nigeria. Int J Womens Health. 2011;3:313-7.

144. Wamai RG, Ayissi CA, Oduwo GO, Perlman S, Welty E, Manga S, et al. Assessing the effectiveness of a community-based sensitization strategy in creating awareness about HPV, cervical cancer and HPV vaccine among parents in North West Cameroon. J Community Health. 2012;37(5):917-26.

145. Becker-Dreps S, Otieno WA, Brewer NT, Agot K, Smith JS. HPV vaccine acceptability among Kenyan women. Vaccine. 2010;28(31):4864-7.

146. W Liu F, Vwalika B. Cervical Cancer and HPV Vaccination: Knowledge and Attitudes of Adult Women in Lusaka, Zambia. J Vaccines Vaccin [Internet]. 2012 [cited 2014 Oct 2];03(03). Available from: http://www.omicsonline.org/ 2157-7560/2157-7560-3-138.digital/2157-7560-3-138.html. Accessed 6 July 2015
147. Poole D, Tracy K, Levitz L, Yekta S, Kossow E, Huang T, et al. Knowledge/ attitude/practices of HPV \&amp; cervical cancer, willingness to participate in vaccine trial in preparation for HIV \&amp; HPV vaccine trials in Mali. Retrovirology. 2012;9 Suppl 2:027.

148. Hoque ME, Van Hal G. Acceptability of Human Papillomavirus Vaccine: A Survey among Master of Business Administration Students in KwaZulu-Natal, South Africa. BioMed Res Int. 2014;2014:257807.

149. Mouallif M, Bowyer HL, Festali S, Albert A, Filali-Zegzouti Y, Guenin S, et al. Cervical cancer and HPV: Awareness and vaccine acceptability among parents in Morocco. Vaccine. 2014;32(3):409-16.

150. Harries J, Moodley J, Barone MA, Mall S, Sinanovic E. Preparing for HPV vaccination in South Africa: key challenges and opinions. Vaccine. 2009;27(1):38-44.

151. Francis SA, Katz ML. The HPV Vaccine: A Comparison of Focus Groups Conducted in South Africa and Ohio Appalachia. Matern Child Health J. 2013:17(7):1222-9.

152. El-Khatib Z, Tota JE, Kaufmann AM. Progress on human papillomavirus (HPV) infection and cervical cancer prevention in sub-Saharan Africa: Highlights of the 27th International Papillomavirus Conference in Berlin, 17-22 September 2011. J Epidemiol Glob Health. 2012;2(2):99-102.

153. Galagan SR, Paul P, Menezes L, LaMontagne DS. Influences on parental acceptance of HPV vaccination in demonstration projects in Uganda and Vietnam. Vaccine. 2013;31(30):3072-8.

154. Binagwaho A, Wagner C, Gatera M, Karema C, Nutt C, Ngaboa F. Achieving high coverage in Rwanda's national human papillomavirus vaccination programme. Bull World Health Organ. 2012;90(8):623-8.

155. Ladner J, Besson M-H, Rodrigues M, Audureau E, Saba J. Performance of 21 HPV vaccination programs implemented in low and middle-income countries, 2009-2013. BMC Public Health. 2014;14(1):670.

156. Ogembo JG, Manga S, Nulah K, Foglabenchi LH, Perlman S, Wamai RG, et al. Achieving high uptake of human papillomavirus vaccine in Cameroon: Lessons learned in overcoming challenges. Vaccine. 2014;32(35):4399-403.

157. LaMontagne DS, Barge S, Le NT, Mugisha E, Penny ME, Gandhi S, et al. Human papillomavirus vaccine delivery strategies that achieved high coverage in lowand middle-income countries. Bull World Health Organ. 2011;89(11):821-30B.

158. Katz IT, Nkala B, Dietrich J, Wallace M, Bekker L-G, Pollenz K, et al. A Qualitative Analysis of Factors Influencing HPV Vaccine Uptake in Soweto, South Africa among Adolescents and Their Caregivers. PLoS ONE. 2013; 8(8):e72094. Sued O, editor.

159. Moodley I, Tathiah N, Mubaiwa V, Denny L. High uptake of Gardasil vaccine among 9-12-year-old schoolgirls participating in an HPV vaccination demonstration project in KwaZulu-Natal, South Africa. South Afr Med J SuidAfr Tydskr Vir Geneeskd. 2013;103(5):318-21.

160. Watson-Jones D, Baisley K, Ponsiano R, Lemme F, Remes P, Ross D, et al. Human Papillomavirus Vaccination in Tanzanian Schoolgirls: ClusterRandomized Trial Comparing 2 Vaccine-Delivery Strategies. J Infect Dis. 2012;206(5):678-86.

161. Kojic EM, Kang M, Cespedes MS, Umbleja T, Godfrey C, Allen RT, et al. Immunogenicity and Safety of the Quadrivalent Human Papillomavirus Vaccine in HIV-1-Infected Women. Clin Infect Dis. 2014;59(1):127-35.

162. Denny L, Hendricks B, Gordon C, Thomas F, Hezareh M, Dobbelaere K, et al. Safety and immunogenicity of the HPV-16/18 AS04-adjuvanted vaccine in HIV-positive women in South Africa: a partially-blind randomised placebocontrolled study. Vaccine. 2013;31(48):5745-53.

163. Botha H, Cooreman B, Dreyer G, Lindeque G, Mourton A, Guidozzi F, et al. Cervical cancer and human papillomavirus: South African guidelines for screening and testing. South Afr J Gynaecol Oncol. 2010;2(1):23-6.

164. Sow PS, Watson-Jones D, Kiviat N, Changalucha J, Mbaye KD, Brown J, et al. Safety and Immunogenicity of Human Papillomavirus-16/18 AS04Adjuvanted Vaccine: A Randomized Trial in 10-25-Year-Old HIV-Seronegative African Girls and Young Women. J Infect Dis. 2013;207(11):1753-63.

165. Brown J, Baisley K, Kavishe B, Changalucha J, Andreasen A, Mayaud P, et al. Impact of malaria and helminth infections on immunogenicity of the human papillomavirus-16/18 AS04-adjuvanted vaccine in Tanzania. Vaccine. 2014;32(5):611-7.

166. Jain KM, Paul P, LaMontagne DS. Monitoring adverse events following immunisation in developing countries: experience from human papillomavirus vaccination demonstration projects. Sex Health. 2013;10(1):57-63.

167. Botha $\mathrm{MH}$, Dochez $\mathrm{C}$. Introducing human papillomavirus vaccines into the health system in South Africa. Vaccine. 2012;30 Suppl 3:C28-34.

168. Gulland A. Uganda launches HPV vaccination programme to fight its commonest cancer. BMJ. 2012;345(sep10 1):e6055-5. 
169. Biddlecom A, Bankole A, Patterson K. Vaccine for cervical cancer: reaching adolescents in sub-Saharan Africa. Lancet. 2006;367:1299-300.

170. Baussano I, Lazzarato F, Ronco G, Dillner J, Franceschi S. Benefits of catch-up in vaccination against human papillomavirus in medium- and low-income countries. Int J Cancer J Int Cancer. 2013;133(8):1876-81.

171. Gray RH, Serwadda D, Kong X, Makumbi F, Kigozi G, Gravitt PE, et al. Male Circumcision Decreases Acquisition and Increases Clearance of High-Risk Human Papillomavirus in HIV-Negative Men: A Randomized Trial in Rakai, Uganda. J Infect Dis. 2010;201(10):1455-62.

172. Tobian AAR, Kong X, Gravitt PE, Eaton KP, Kigozi G, Serwadda D, et al. Male circumcision and anatomic sites of penile high-risk human papillomavirus in Rakai, Uganda. Int J Cancer. 2011;129(12):2970-5.

173. Wawer M, Tobian AA, Kigozi G, Kong X, Gravitt PE, Serwadda D, et al. Male Circumcision Reduces Human Papillomavirus Transmission to HIV-Negative Female Partners: A Randomized Trial in Rakai, Uganda. Lancet. 2011;377(9761):209-18.

174. Tobian AAR, Kong X, Wawer MJ, Kigozi G, Gravitt PE, Serwadda D, et al. Circumcision of HIV-infected men and transmission of human papillomavirus to female partners: analyses of data from a randomised trial in Rakai, Uganda. Lancet Infect Dis. 2011;11(8):604-12.

175. Tarnaud C, Lissouba P, Cutler E, Puren A, Taljaard D, Auvert B. Association of low-risk human papillomavirus infection with male circumcision in young men: results from a longitudinal study conducted in Orange Farm (South Africa). Infect Dis Obstet Gynecol. 2011;2011:567408.

176. Davis M-A, Gray RH, Grabowski MK, Serwadda D, Kigozi G, Gravitt PE, et al. Male circumcision decreases high-risk human papillomavirus viral load in female partners: a randomized trial in Rakai, Uganda. Int J Cancer J Int Cancer. 2013;133(5):1247-52.

177. Sawaya GF, Chirenje MZ, Magure MT, Tuveson JL, Ma Y, Shiboski SC, et al. Effect of Diaphragm and Lubricant Gel Provision on Human Papillomavirus Infection Among Women Provided With Condoms: A Randomized Controlled Trial. Obstet Gynecol. 2008;112(5):990-7.

178. Marais D, Gawarecki D, Allan B, Ahmed K, Altini L, Cassim N, et al. The effectiveness of Carraguard, a vaginal microbicide, in protecting women against high-risk human papillomavirus infection. Antivir Ther. 2011;16(8):1219-26.

179. Maree JE. "No condom, no sex": Easy to say, but not possible for all South African women. Health SA Gesondheid [Internet]. 2010 Mar 17 [cited 2015 May 14];15(1). Available from: http://www.hsag.co.za/index.php/HSAG/article/view/506. Accessed 6 July 2015

180. Watson-Jones D, Tomlin K, Remes P, Baisley K, Ponsiano R, Soteli S, et al. Reasons for Receiving or Not Receiving HPV Vaccination in Primary Schoolgirls in Tanzania: A Case Control Study. PLoS ONE. 2012;7(10):e45231. Niccolai LM, editor.

181. Quentin W, Terris-Prestholt F, Changalucha J, Soteli S, Edmunds WJ, Hutubessy $R$, et al. Costs of delivering human papillomavirus vaccination to schoolgirls in Mwanza Region, Tanzania. BMC Med. 2012;10:137.

182. Untiet S, Vassilakos P, McCarey C, Tebeu P-M, Kengne-Fosso G, Menoud P-A, et al. HPV self-sampling as primary screening test in sub-Saharan Africa: implication for a triaging strategy. Int J Cancer J Int Cancer. 2014;135(8):1911-7.

183. Adler DH, Laher F, Lazarus E, Grzesik K, Gray GE, Allan B, et al. A Viable and Simple Self-Sampling Method for Human Papillomavirus Detection among South African Adolescents. J Immunol Tech Infect Dis. $2013 ; 18: 2(3)$

184. Ting J, Mugo N, Kwatampora J, Hill C, Chitwa M, Patel S, et al. High-risk human papillomavirus messenger RNA testing in physician- and selfcollected specimens for cervical lesion detection in high-risk women, Kenya. Sex Transm Dis. 2013;40(7):584-9.

185. Safaeian M, Kiddugavu M, Gravitt PE, Ssekasanvu J, Murokora D, Sklar M, et al. Comparability of self-collected vaginal swabs and physician-collected cervical swabs for detection of human papillomavirus infections in Rakai, Uganda. Sex Transm Dis. 2007;34(7):429-36.

186. Kamal EM, El Sayed GA, El Behery MM, El Shennawy GA. HPV detection in a self-collected vaginal swab combined with VIA for cervical cancer screening with correlation to histologically confirmed CIN. Arch Gynecol Obstet. 2014; 290(6):1207-13.

187. Adler DH, Almudevar A, Gray GE, Allan B, Williamson A-L. High level of agreement between clinician-collected and self-collected samples for HPV detection among South African adolescents. J Pediatr Adolesc Gynecol. 2012;25(4):280-1.

188. Jones HE, Allan BR, van de Wijgert JHHM, Altini L, Taylor SM, de Kock A, et al. Agreement between self- and clinician-collected specimen results for detection and typing of high-risk human papillomavirus in specimens from women in Gugulethu, South Africa. J Clin Microbiol. 2007;45(6):1679-83.
189. Taylor S, Wang C, Wright TC, Denny L, Kuhn L. A comparison of human papillomavirus testing of clinician-collected and self-collected samples during follow-up after screen-and-treat. Int J Cancer. 2011;129(4):879-86.

190. Charbonneau V, Garrigue I, Jaquet A, Horo A, Minga A, Recordon-Pinson P, et al. Dried cervical spots for human papillomaviruses identification. J Med Virol. 2013;85(7):1222-8.

191. Alidjinou EK, Ebatetou-Ataboho E, Sané F, Moukassa D, Dewilde A, Hober D. Cervical samples dried on filter paper and dried vaginal tampons can be useful to investigate the circulation of high-risk HPV in Congo. J Clin Virol Off Publ Pan Am Soc Clin Virol. 2013;57(2):161-4.

192. Lack N, West B, Jeffries D, Ekpo G, Morison L, Soutter WP, et al. Comparison of non-invasive sampling methods for detection of HPV in rural African women. Sex Transm Infect. 2005;81(3):239-41.

193. Bigoni J, Gundar M, Tebeu P-M, Bongoe A, Schäfer S, Fokom-Domgue J, et al. Cervical cancer screening in sub-Saharan Africa: A randomized trial of VIA versus cytology for triage of HPV-positive women. Int J Cancer J Int Cancer. 2015;137(1):127-34

194. Stock EM, Stamey JD, Sankaranarayanan R, Young DM, Muwonge R, Arbyn M. Estimation of disease prevalence, true positive rate, and false positive rate of two screening tests when disease verification is applied on only screen-positives: a hierarchical model using multi-center data. Cancer Epidemiol. 2012;36(2):153-60.

195. Sangwa-Lugoma G, Mahmud S, Nasr SH, Liaras J, Kayembe PK, Tozin RR, et al. Visual inspection as a cervical cancer screening method in a primary health care setting in Africa. Int J Cancer. 2006;119(6):1389-95.

196. Ngoma T, Muwonge R, Mwaiselage J, Kawegere J, Bukori P, Sankaranarayanan R. Evaluation of cervical visual inspection screening in Dar es Salaam, Tanzania. Int J Gynaecol Obstet Off Organ Int Fed Gynaecol Obstet. 2010;109(2):100-4.

197. Muwonge R, Manuel Mda G, Filipe AP, Dumas JB, Frank MR, Sankaranarayanan R. Visual screening for early detection of cervical neoplasia in Angola. Int J Gynecol Obstet. 2010;111(1):68-72.

198. Hovland S, Arbyn M, Lie AK, Ryd W, Borge B, Berle EJ, et al. A comprehensive evaluation of the accuracy of cervical pre-cancer detection methods in a high-risk area in East Congo. Br J Cancer. 2010;102(6):957-65.

199. Mwanahamuntu MH, Sahasrabuddhe W, Kapambwe S, Pfaendler KS, Chibwesha C, Mkumba G, et al. Advancing Cervical Cancer Prevention Initiatives in Resource-Constrained Settings: Insights from the Cervical Cancer Prevention Program in Zambia. PLoS Med. 2011;8(5):e1001032.

200. Paul P, Winkler JL, Bartolini RM, Penny ME, Huong TT, Nga LT, et al. Screen-andtreat approach to cervical cancer prevention using visual inspection with acetic acid and cryotherapy: experiences, perceptions, and beliefs from demonstration projects in Peru, Uganda, and Vietnam. Oncologist. 2013;18(Suppl):6-12.

201. White HL, Mulambia C, Sinkala M, Mwanahamuntu MH, Parham GP Kapambwe S, et al. Motivations and experiences of women who accessed "see and treat" cervical cancer prevention services in Zambia. J Psychosom Obstet Gynaecol. 2012;33(2):91-8.

202. Mwanahamuntu MH, Sahasrabuddhe W, Pfaendler KS, Mudenda V, Hicks ML, Vermund SH, et al. Implementation of "see-and-treat" cervical cancer prevention services linked to HIV care in Zambia. AIDS Lond Engl. 2009;23(6):N1-5.

203. Fokom-Domgue J, Vassilakos P, Petignat P. Is screen-and-treat approach suited for screening and management of precancerous cervical lesions in Sub-Saharan Africa? Prev Med. 2014;65:138-40.

204. Rositch AF, Gatuguta A, Choi RY, Guthrie BL, Mackelprang RD, Bosire R, et al. Knowledge and Acceptability of Pap Smears, Self-Sampling and HPV Vaccination among Adult Women in Kenya. PLoS ONE. 2012;7(7):e40766. Medeiros $\mathrm{R}$, editor.

205. Ibekwe CM, Hoque ME, Ntuli-Ngcobo B. Perceived benefits of cervical cancer screening among women attending Mahalapye District Hospital, Botswana. Asian Pac J Cancer Prev APJCP. 2010;11(4):1021-7.

206. Busingye $P$, Nakimuli A, Nabunya E, Mutyaba T. Acceptability of cervical cancer screening via visual inspection with acetic acid or Lugol's iodine at Mulago Hospital, Uganda. Int J Gynaecol Obstet Off Organ Int Fed Gynaecol Obstet. 2012;119(3):262-5.

207. Audet CM, Silva Matos C, Blevins M, Cardoso A, Moon TD, Sidat M. Acceptability of cervical cancer screening in rural Mozambique. Health Educ Res. 2012;27(3):544-51.

208. Tchounga BK, Jaquet A, Coffie PA, Horo A, Sauvaget C, Adoubi I, et al. Cervical cancer prevention in reproductive health services: knowledge, attitudes and practices of midwives in Côte d'Ivoire, West Africa. BMC Health Serv Res. 2014;14:165. 
209. Urasa M, Darj E. Knowledge of cervical cancer and screening practices of nurses at a regional hospital in Tanzania. Afr Health Sci. 2011;11(1):48-57.

210. Mutyaba T, Mmiro FA, Weiderpass E. Knowledge, attitudes and practices on cervical cancer screening among the medical workers of Mulago Hospital, Uganda. BMC Med Educ. 2006;6:13.

211. Anya SE, Oshi DC, Nwosu SO, Anya AE. Knowledge, attitude, and practice of female health professionals regarding cervical cancer and Pap smear. Niger J Med J Natl Assoc Resid Dr Niger. 2005;14(3):283-6.

212. Ginsberg GM, Lauer JA, Zelle S, Baeten S, Baltussen R. Cost effectiveness of strategies to combat breast, cervical, and colorectal cancer in sub-Saharan Africa and South East Asia: mathematical modelling study. BMJ. 2012;344:e614.

213. Vijayaraghavan A, Efrusy M, Lindeque G, Dreyer G, Santas C. Cost effectiveness of high-risk HPV DNA testing for cervical cancer screening in South Africa. Gynecol Oncol. 2009;112(2):377-83.

214. Sinanovic E, Moodley J, Barone MA, Mall S, Cleary S, Harries J. The potential cost-effectiveness of adding a human papillomavirus vaccine to the cervical cancer screening programme in South Africa. Vaccine. 2009;27(44):6196-202.

215. Mwaka AD, Wabinga HR, Mayanja-Kizza H. Mind the gaps: a qualitative study of perceptions of healthcare professionals on challenges and proposed remedies for cervical cancer help-seeking in post conflict northern Uganda. BMC Fam Pract. 2013;14:193.

216. Moon TD, Silva-Matos C, Cordoso A, Baptista AJ, Sidat M, Vermund SH. Implementation of cervical cancer screening using visual inspection with acetic acid in rural Mozambique: successes and challenges using HIV care and treatment programme investments in Zambézia Province. J Int AIDS Soc. 2012;15(2):17406.

217. Sanghvi H, Limpaphayom KK, Plotkin M, Charurat E, Kleine A, Lu E, et al. Cervical cancer screening using visual inspection with acetic acid: operational experiences from Ghana and Thailand. Reprod Health Matters. 2008;16(32):67-77.

218. Kawonga M, Fonn S. Achieving effective cervical screening coverage in South Africa through human resources and health systems development. Reprod Health Matters. 2008;16(32):32-40.

219. Sibiya MN, Grainger L. An assessment of the implementation of the provincial cervical screening programme in selected Primary Health Care Clinics in the llembe Region, KwaZulu-Natal. Curationis. 2007;30(1):48-55.

220. Anorlu RI, Ribiu KA, Abudu OO, Ola ER. Cervical cancer screening practices among general practitioners in Lagos Nigeria. J Obstet Gynaecol J Inst Obstet Gynaecol. 2007;27(2):181-4.

221. Williams MS, Amoateng P. Knowledge and beliefs about cervical cancer screening among men in Kumasi, Ghana. Ghana Med J. 2012;46(3):147-51.

222. Mutyaba T, Mirembe F, Sandin S, Weiderpass E. Male partner involvement in reducing loss to follow-up after cervical cancer screening in Uganda. Int J Gynaecol Obstet Off Organ Int Fed Gynaecol Obstet. 2009;107(2):103-6.

223. Smith JS, Moses S, Hudgens MG, Agot K, Franceschi S, Maclean IW, et al. Human papillomavirus detection by penile site in young men from Kenya. Sex Transm Dis. 2007;34(11):928-34

224. Horo A, Jaquet A, Ekouevi DK, Toure B, Coffie PA, Effi B, et al. Cervical cancer screening by visual inspection in Côte $d^{\prime}$ Ivoire, operational and clinical aspects according to HIV status. BMC Public Health. 2012;12:237.

225. Dim CC, Dim NR, Ezegwui HU, Ikeme AC. An unmet cancer screening need of HIV-positive women in southeastern Nigeria. Medscape J Med. 2009;11(1):19.

226. Kuhn L, Wang C, Tsai W-Y, Wright TC, Denny L. Efficacy of human papillomavirus-based screen-and-treat for cervical cancer prevention among HIV-infected women. AIDS Lond Engl. 2010;24(16):2553-61.

227. Rabiu KA, Akinbami AA, Adewunmi AA, Akinola Ol, Wright KO. The need to incorporate routine cervical cancer counselling and screening in the management of HIV positive women in Nigeria. Asian Pac J Cancer Prev APJCP. 2011;12(5):1211-4.

228. Wake RM, Rebe K, Burch VC. Patient perception of cervical screening among women living with human immuno-deficiency virus infection attending an antiretroviral therapy clinic in urban South Africa. J Obstet Gynaecol J Inst Obstet Gynaecol. 2009;29(1):44-8.

229. Huchko MJ, Bukusi EA, Cohen CR. Building capacity for cervical cancer screening in outpatient HIV clinics in the Nyanza province of western Kenya. Int J Gynaecol Obstet Off Organ Int Fed Gynaecol Obstet. 2011;114(2):106-10.

230. Atashili J, Smith JS, Adimora AA, Eron J, Miller WC, Myers E. Potential impact of antiretroviral therapy and screening on cervical cancer mortality in HIV-positive women in sub-Saharan Africa: a simulation. PLOS ONE. 2011;6(4):e18527.
231. Franceschi S, Jaffe H. Cervical Cancer Screening of Women Living with HIV Infection: A Must in the Era of Antiretroviral Therapy. Clin Infect Dis. 2007; 45(4):510-3.

232. Quinley KE, Gormley RH, Ratcliffe SJ, Shih T, Szep Z, Steiner A, et al. Use of mobile telemedicine for cervical cancer screening. J Telemed Telecare. 2011; 17(4):203-9.

233. Mushosho EY, Ndlovu N, Engel-Hills P, Wyrley-Birch B. Presentation patterns of invasive cancer of the cervix: results from Parirenyatwa Oncology and Radiotherapy Centre, Harare, Zimbabwe 1998-2010. Cent Afr J Med. 2011; 57(9-12):43-9.

234. Snyman LC, Herbst U. Reasons why unscreened patients with cervical cancer present with advanced stage disease. South Afr J Gynaecol Oncol. 2013;5(1):16-20

235. Woo VG, Cohen CR, Bukusi EA, Huchko MJ. Loop Electrosurgical Excision Procedure: Safety and Tolerability Among Human Immunodeficiency VirusPositive Kenyan Women. Obstet Gynecol. 2011;118(3):554-9.

236. Mungo C, Cohen CR, Maloba M, Bukusi EA, Huchko MJ. Prevalence, characteristics, and outcomes of HIV-positive women diagnosed with invasive cancer of the cervix in Kenya. Int J Gynaecol Obstet Off Organ Int Fed Gynaecol Obstet. 2013;123(3):231-5.

237. AORTIC. Cancer Plan for the African Continent [Internet]. 2013. Available from: http://www.iccp-portal.org/sites/default/files/plans/AORTIC_CANCER_ PLAN\%20AFRICA.pdf. Accessed 6 July 2015.

238. Kigula-Mugambe JB, Kavuma A. Effect of HIV serological status on outcome in patients with cancer of cervix treated with radiotherapy. East Afr Med J. 2006;83(8):416-23.

239. Gichangi P, Bwayo J, Estambale B, Rogo K, Njuguna E, Ojwang S, et al. HIV impact on acute morbidity and pelvic tumor control following radiotherapy for cervical cancer. Gynecol Oncol. 2006;100(2):405-11.

240. Moodley M, Mould S. Invasive cervical cancer and human immunodeficiency virus (HIV) infection in KwaZulu-Natal, South Africa. J Obstet Gynaecol J Inst Obstet Gynaecol. 2005;25(7):706-10.

241. Denslow SA, Rositch AF, Firnhaber C, Ting J, Smith JS. Incidence and progression of cervical lesions in women with HIV: a systematic global review. Int J STD AIDS. 2014;25(3):163-77.

242. van Bogaert $L-J$. The impact of human immunodeficiency virus infection on cervical preinvasive and invasive neoplasia in South Africa. Ecancermedicalscience. 2013;7:334.

243. Simonds HM, Wright JD, du Toit N, Neugut Al, Jacobson JS. Completion of and early response to chemoradiation among human immunodeficiency virus (HIV)-positive and HIV-negative patients with locally advanced cervical carcinoma in South Africa. Cancer. 2012;118(11):2971-9.

244. Huchko MJ, Leslie H, Maloba M, Bukusi EA, Cohen CR. Factors associated with recurrence of cervical intraepithelial neoplasia 2+ after treatment among HIV-infected women in Western Kenya. J Acquir Immune Defic Syndr. 2014;66(2):188-92.

245. Hank E, Hoque ME, Zungu L. Cervical precancerous lesions and cancer among patients in the gynaecology outpatient department at a tertiary hospital in South Africa. Asian Pac J Cancer Prev APJCP. 2013;14(8):4903-6.

246. Flepisi BT, Bouic P, Sissolak G, Rosenkranz B. Drug-drug interactions in HIV positive cancer patients. Biomed Pharmacother. 2014;68(5):665-77.

247. Zeier MD, Botha MH, van der Merwe FH, Eshun-Wilson I, van Schalkwyk M, la Grange $M$, et al. Progression and persistence of low-grade cervical squamous intraepithelial lesions in women living with human immunodeficiency virus. J Low Genit Tract Dis. 2012;16(3):243-50.

248. Zeier MD, Nachega JB, Van Der Merwe FH, Eshun-Wilson I, Van Schalkwyk M, La Grange M, et al. Impact of timing of antiretroviral therapy initiation on survival of cervical squamous intraepithelial lesions: a cohort analysis from South Africa. Int J STD AIDS. 2012;23(12):890-6.

249. Logie DE, Harding R. An evaluation of a morphine public health programme for cancer and AIDS pain relief in Sub-Saharan Africa. BMC Public Health. 2005;5:82

250. Omoyeni N, Soyannwo O, Aikomo O, Iken O. Home-based palliative care for adult cancer patients in Ibadan-a three year review. Ecancermedicalscience. 2014;8:490.

251. Rawlinson F. The current situation in education and training of health-care professionals across Africa to optimise the delivery of palliative care for cancer patients. ecancermedicalscience [Internet]. 2014 Dec 11 [cited 2015 May 14];8. Available from: http://www.ecancer.org/journal/8/full/492-the-current-situationin-education-and-training-of-health-care-professionals-across-africa-to-optimisethe-delivery-of-palliative-care-for-cancer-patients.php. Accessed 6 July 2015. 
252. Selman L, Higginson IJ, Agupio G, Dinat N, Downing J, Gwyther L, et al. Meeting information needs of patients with incurable progressive disease and their families in South Africa and Uganda: multicentre qualitative study. BMJ. 2009;338:b1326.

253. Harding R, Higginson IJ. Palliative care in sub-Saharan Africa. Lancet. 2005; 365(9475):1971-7.

254. Atuhairwe S, Busingye RB, Sekikubo M, Nakimuli A, Mutyaba T. Urologic complications among women with advanced cervical cancer at a tertiary referral hospital in Uganda. Int J Gynaecol Obstet Off Organ Int Fed Gynaecol Obstet. 2011;115(3):282-4.

255. Ntekim A. Cervical Cancer in Sub Sahara Africa. In: R. Rajamanickam, editor Topics on Cervical Cancer With an Advocacy for Prevention [Internet]. InTech; 2012 [cited 2015 May 14]. Available from: http://www.intechopen. com/books/topics-on-cervical-cancer-with-an-advocacy-for-prevention/ cervical-cancer-in-sub-sahara-africa. Accessed 6 July 2015.

256. Ezeanochie MC, Olagbuji BN. Human papilloma virus vaccine: determinants of acceptability by mothers for adolescents in Nigeria. Afr J Reprod Health. 2014;18(3):154-8.

257. Omondi-Ogutu, M'Imunya J. Parental Acceptance of Human Papilloma Virus Vaccine for Their Pre-Pubertal and Teenage Daughters. East Afr Med J. 2011;88(5): 163-70.

258. Kane MA, Serrano B, de Sanjosé S, Wittet S. Implementation of Human Papillomavirus Immunization in the Developing World. Vaccine. 2012;30:F192-200.

259. Tsu VD, Cernuschi T, LaMontagne DS. Lessons Learned From HPV Vaccine Delivery in Low-Resource Settings and Opportunities for HIV Prevention, Treatment, and Care Among Adolescents. JAIDS J Acquir Immune Defic Syndr. 2014;66:S209-16.

260. Binagwaho A, Ngabo F, Wagner CM, Mugeni C, Gatera M, Nutt CT, et al. Integration of comprehensive women's health programmes into health systems: cervical cancer prevention, care and control in Rwanda. Bull World Health Organ. 2013;91(9):697-703.

261. Levin CE, Van Minh H, Odaga J, Rout SS, Ngoc DNT, Menezes L, et al. Delivery cost of human papillomavirus vaccination of young adolescent girls in Peru, Uganda and Viet Nam. Bull World Health Organ. 2013;91(8):585-92.

262. Louie KS, De Sanjose S, Mayaud P. Epidemiology and prevention of human papillomavirus and cervical cancer in sub-Saharan Africa: a comprehensive review: Epidemiology of human papillomavirus. Trop Med Int Health. 2009; 14(10):1287-302.

263. Tracy JK, Schluterman NH, Greene C, Sow SO, Gaff HD. Planning for human papillomavirus (HPV) vaccination in sub-Saharan Africa: a modeling-based approach. Vaccine. 2014;32(26):3316-22.

264. Kim JJ, Sharma M, O'Shea M, Sweet S, Diaz M, Sancho-Garnier H, et al. Modelbased impact and cost-effectiveness of cervical cancer prevention in the Extended Middle East and North Africa (EMENA). Vaccine. 2013;31 Suppl 6:G65-77.

265. Demarteau N, Morhason-Bello IO, Akinwunmi B, Adewole IF. Modeling optimal cervical cancer prevention strategies in Nigeria. BMC Cancer. 2014;14:365.

266. Kim S-Y, Sweet S, Chang J, Goldie SJ. Comparative evaluation of the potential impact of rotavirus versus HPV vaccination in GAVI-eligible countries: a preliminary analysis focused on the relative disease burden BMC Infect Dis. 2011;11:174.

267. Campos NG, Kim JJ, Castle PE, Ortendahl JD, O'Shea M, Diaz M, et al. Health and economic impact of HPV 16/18 vaccination and cervical cancer screening in Eastern Africa. Int J Cancer J Int Cancer. 2012:130(11):2672-84.

268. Goldie SJ, O'Shea M, Campos NG, Diaz M, Sweet S, Kim S-Y. Health and economic outcomes of HPV 16,18 vaccination in 72 GAVI-eligible countries. Vaccine. 2008;26(32):4080-93.

269. Hutubessy R, Levin A, Wang S, Morgan W, Ally M, John T, et al. A case study using the United Republic of Tanzania: costing nationwide HPV vaccine delivery using the WHO Cervical Cancer Prevention and Control Costing Tool. BMC Med. 2012;10:136.

270. Tracy L, Gaff HD, Burgess C, Sow S, Gravitt PE, Tracy JK. Estimating the impact of human papillomavirus (HPV) vaccination on HPV prevalence and cervical cancer incidence in Mali. Clin Infect Dis Off Publ Infect Dis Soc Am. 2011;52(5):641-5.

271. Kiatpongsan S, Campos NG, Kim JJ. Potential benefits of second-generation human papillomavirus vaccines. PLoS ONE. 2012;7(11):e48426.

272. Lee LA, Franzel L, Atwell J, Datta SD, Friberg IK, Goldie SJ, et al. The estimated mortality impact of vaccinations forecast to be administered during 2011-2020 in 73 countries supported by the GAVI Alliance. Vaccine. 2013;31:B61-72.

273. Kane MA. Preventing Cancer with Vaccines: Progress in the Global Control of Cancer. Cancer Prev Res (Phila Pa). 2012;5(1):24-9.
274. Banura C, Mirembe FM, Katahoire AR, Namujju PB, Mbidde EK. Universal routine HPV vaccination for young girls in Uganda: a review of opportunities and potential obstacles. Infect Agent Cancer. 2012;7(1):24.

275. Jumaan AO, Ghanem S, Taher J, Braikat M, Awaidy SA, Dbaibo GS. Prospects and Challenges in the Introduction of Human Papillomavirus Vaccines in the Extended Middle East and North Africa Region. Vaccine. 2013;31:G58-64.

276. van Bogaert $\mathrm{L}$. Are the currently existing anti-human papillomavirus vaccines appropriate for the developing world? Ann Med Health Sci Res. 2013;3(3):306-12.

277. Wilson LE, Gravitt P, Tobian AAR, Kigozi G, Serwadda D, Nalugoda F, et al. Male circumcision reduces penile high-risk human papillomavirus viral load in a randomised clinical trial in Rakai, Uganda. Sex Transm Infect. 2013;89(3):262-6.

278. Sanad AS, Ibrahim EM, Gomaa W. Evaluation of cervical biopsies guided by visual inspection with acetic acid. J Low Genit Tract Dis. 2014;18(1):21-5.

279. Ajenifuja KO, Gage JC, Adepiti AC, Wentzensen N, Eklund C, Reilly M, et al. A population-based study of visual inspection with acetic acid (VIA) for cervical screening in rural Nigeria. Int J Gynecol Cancer Off J Int Gynecol Cancer Soc. 2013:23(3):507-12.

280. Muwonge R, Walter SD, Wesley RS, Basu P, Shastri SS, Thara S, et al. Assessing the gain in diagnostic performance when two visual inspection methods are combined for cervical cancer prevention. J Med Screen. 2007;14(3):144-50.

281. Gaffikin L, McGrath JA, Arbyn M, Blumenthal PD. Visual inspection with acetic acid as a cervical cancer test: accuracy validated using latent class analysis. BMC Med Res Methodol. 2007:7:36.

282. Sankaranarayanan R, Basu P, Wesley RS, Mahe C, Keita N, Mbalawa CCG, et al. Accuracy of visual screening for cervical neoplasia: Results from an IARC multicentre study in India and Africa. Int J Cancer J Int Cancer. 2004; 110(6):907-13.

283. Gaffikin L, McGrath J, Arbyn M, Blumenthal PD. Avoiding verification bias in screening test evaluation in resource poor settings: a case study from Zimbabwe. Clin Trials Lond Engl. 2008;5(5):496-503.

284. Sauvaget C, Fayette J-M, Muwonge R, Wesley R, Sankaranarayanan R. Accuracy of visual inspection with acetic acid for cervical cancer screening. Int J Gynaecol Obstet Off Organ Int Fed Gynaecol Obstet. 2011;113(1):14-24.

285. Godfrey CC, Michelow PM, Godard M, Sahasrabuddhe W, Darden J, Firnhaber CS, et al. Improving diagnostic capability for HPV disease internationally within the NIH-NIAID Division of AIDS Clinical Trial Networks. Am J Clin Pathol. 2013;140(6):881-9.

286. Berner A, Hassel SB, Tebeu P-M, Untiet S, Kengne-Fosso G, Navarria I, et al. Human papillomavirus self-sampling in Cameroon: women's uncertainties over the reliability of the method are barriers to acceptance. J Low Genit Tract Dis. 2013;17(3):235-41.

287. Gage JC, Ajenifuja KO, Wentzensen N, Adepiti AC, Stoler M, Eder PS, et al. Effectiveness of a simple rapid human papillomavirus DNA test in rural Nigeria. Int J Cancer J Int Cancer. 2012;131(12):2903-9.

288. Handlogten KS, Molitor RJ, Roeker LE, Narla NP, Bachman MJ, Quayson S, et al. Cervical cancer screening in Ghana, west Africa: prevalence of abnormal cytology and challenges for expanding screening. Int J Gynecol Pathol Off J Int Soc Gynecol Pathol. 2014;33(2):197-202.

289. Akinremi TO, Nazeer S, Tötsch M. Reduced alcohol use in the staining of Pap smears: a satisfactory low-cost protocol for cervical cancer screening. Acta Cytol. 2005:49(2):169-72.

290. Taylor S, Kuhn L, Dupree W, Denny L, De Souza M, Wright TC. Direct comparison of liquid-based and conventional cytology in a South African screening trial. Int J Cancer J Int Cancer. 2006;118(4):957-62.

291. Muwonge R, Mbalawa CG, Keita N, Dolo A, Nouhou H, Nacoulma M, et al. Performance of colposcopy in five sub-Saharan African countries. BJOG Int J Obstet Gynaecol. 2009;116(6):829-37.

292. van Bogaert L-J. Influence of knowledge of human immunodeficiency virus serostatus on accuracy of cervical cytologic diagnosis. Cancer Cytopathol. 2014;122(12):909-13.

293. Olagbuji BN, Okonkwo CA, Akhiwu W. Evaluation of diagnostic performances of visual cervical inspection with acetic acid and colposcopy in Benin city, Nigeria. West Afr J Med. 2014;33(1):26-31.

294. Mukakalisa I, Bindler R, Allen C, Dotson J. Cervical cancer in developing countries: effective screening and preventive strategies with an application in Rwanda. Health Care Women Int. 2014:35(7-9):1065-80.

295. Dartell MA, Rasch V, Iftner T, Kahesa C, Mwaiselage JD, Junge J, et al. Performance of visual inspection with acetic acid and human papillomavirus testing for detection of high-grade cervical lesions in HIV positive and HIV negative Tanzanian women. Int J Cancer J Int Cancer. 2014;135(4):896-904. 
296. Mahmud SM, Sangwa-Lugoma G, Nasr SH, Kayembe PK, Tozin RR, Drouin P, et al. Comparison of human papillomavirus testing and cytology for cervical cancer screening in a primary health care setting in the Democratic Republic of the Congo. Gynecol Oncol. 2012;124(2):286-91.

297. Cronjé HS. Cervical screening strategies in resourced and resource-constrained countries. Best Pract Res Clin Obstet Gynaecol. 2011;25(5):575-84.

298. Arbyn M, Sankaranarayanan R, Muwonge R, Keita N, Dolo A, Mbalawa CG, et al. Pooled analysis of the accuracy of five cervical cancer screening tests assessed in eleven studies in Africa and India. Int J Cancer J Int Cancer. 2008;123(1):153-60.

299. Allan BR, Marais DJ, Denny L, Hoffman M, Shapiro S, Williamson A-L. The agreement between cervical abnormalities identified by cytology and detection of high-risk types of human papillomavirus. South Afr Med J SuidAfr Tydskr Vir Geneeskd. 2006;96(11):1186-90.

300. Doh AS, Nkele NN, Achu P, Essimbi F, Essame O, Nkegoum B. Visual inspection with acetic acid and cytology as screening methods for cervical lesions in Cameroon. Int J Gynaecol Obstet Off Organ Int Fed Gynaecol Obstet. 2005;89(2):167-73.

301. De Vuyst H, Claeys P, Njiru S, Muchiri L, Steyaert S, De Sutter P, et al. Comparison of pap smear, visual inspection with acetic acid, human papillomavirus DNA-PCR testing and cervicography. Int J Gynaecol Obstet Off Organ Int Fed Gynaecol Obstet. 2005;89(2):120-6.

302. Cuzick J, Arbyn M, Sankaranarayanan R, Tsu V, Ronco G, Mayrand M-H, et al. Overview of Human Papillomavirus-Based and Other Novel Options for Cervical Cancer Screening in Developed and Developing Countries. Vaccine. 2008;26:K29-41.

303. Jeronimo J, Bansil P, Lim J, Peck R, Paul P, Amador JJ, et al. A Multicountry Evaluation of careHPV Testing, Visual Inspection With Acetic Acid, and Papanicolaou Testing for the Detection of Cervical Cancer. Int J Gynecol Cancer. 2014;24(3):576-85.

304. Mwanahamuntu MH, Sahasrabuddhe WV, Blevins M, Kapambwe S, Shepherd BE, Chibwesha C, et al. Monitoring the performance of "screen-and-treat" cervical cancer prevention programs. Int J Gynecol Obstet. 2014;126(1):88-9.

305. Mwanahamuntu MH, Sahasrabuddhe W, Blevins M, Kapambwe S, Shepherd $\mathrm{BE}$, Chibwesha C, et al. Utilization of cervical cancer screening services and trends in screening positivity rates in a "screen-and-treat" program integrated with HIV/AIDS care in Zambia. PLoS ONE. 2013;8(9):e74607.

306. WHO. Prevention of cervical cancer through screening using visual inspection with acetic acid (VIA) and treatment with cryotherapy: A demonstration project in six African countries: Malawi, Madagascar, Nigeria, Uganda,the United Republic of Tanzania, and Zambia [Internet]. 2012. Available from: http://apps.who.int/iris/bitstream/10665/75250/1/ 9789241503860_eng.pdf. Accessed 6 July 2015.

307. Ramogola-Masire D, de Klerk R, Monare B, Ratshaa B, Friedman HM, Zetola NM. Cervical cancer prevention in HIV-infected women using the "see and treat" approach in Botswana. J Acquir Immune Defic Syndr. 1999;59(3):308-13.

308. Denny L, Kuhn L, Hu C-C, Tsai W-Y, Wright TC. Human Papillomavirus-Based Cervical Cancer Prevention: Long-term Results of a Randomized Screening Trial. JNCI J Natl Cancer Inst. 2010;102(20):1557-67.

309. Pfaendler KS, Mwanahamuntu MH, Sahasrabuddhe W, Mudenda V, Stringer JSA, Parham GP. Management of cryotherapy-ineligible women in a "screenand-treat" cervical cancer prevention program targeting HIV-infected women in Zambia: lessons from the field. Gynecol Oncol. 2008;110(3):402-7.

310. Denny L, Kuhn L, De Souza M, Pollack AE, Dupree W, Wright TC. Screenand-treat approaches for cervical cancer prevention in low-resource settings: a randomized controlled trial. JAMA. 2005;294(17):2173-81.

311. Chigbu CO, Onyebuchi AK. See-and-treat management of high-grade squamous intraepithelial lesions in a resource-constrained African setting. Int J Gynaecol Obstet Off Organ Int Fed Gynaecol Obstet. 2014; 124(3):204-6.

312. Arulogun OS, Maxwell OO. Perception and utilization of cervical cancer screening services among female nurses in University College Hospital, Ibadan, Nigeria. Pan Afr Med J. 2012;11:69.

313. McCarey C, Pirek D, Tebeu P, Boulvain M, Doh A, Petignat P. Awareness of HPV and cervical cancer prevention among Cameroonian healthcare workers. BMC Womens Health. 2011;11(1):45.

314. Levine LD, Chudnoff SG, Taylor K, Baganizi M, Banks E. A 5-day educational program for teaching cervical cancer screening using visual inspection with acetic acid in low-resource settings. Int J Gynaecol Obstet Off Organ Int Fed Gynaecol Obstet. 2011;115(2):171-4.
315. Dim CC, Ekwe E, Madubuko T, Dim NR, Ezegwui HU. Improved awareness of Pap smear may not affect its use in Nigeria: a case study of female medical practitioners in Enugu, southeastern Nigeria. Trans R Soc Trop Med Hyg. 2009;103(8):852-4.

316. Miller D, Okolo CA, Mirabal Y, Guillaud M, Arulogun OS, Oladepo O, et al. Knowledge dissemination and evaluation in a cervical cancer screening implementation program in Nigeria. Gynecol Oncol. 2007;107(1 Suppl 1):S196-207.

317. Udigwe GO. Knowledge, attitude and practice of cervical cancer screening (pap smear) among female nurses in Nnewi, South Eastern Nigeria. Niger J Clin Pract. 2006;9(1):40-3.

318. Moodley J, Kawonga M, Bradley J, Hoffman M. Challenges in implementing a cervical screening program in South Africa. Cancer Detect Prev. 2006;30(4): $361-8$.

319. Gharoro EP, Ikeanyi EN. An appraisal of the level of awareness and utilization of the Pap smear as a cervical cancer screening test among female health workers in a tertiary health institution. Int J Gynecol Cancer Off J Int Gynecol Cancer Soc. 2006;16(3):1063-8.

320. Nwobodo El, Malami SA. Knowledge and practice of cervical screening among female health workers in Sokoto, North Western Nigeria. Niger Postgrad Med J. 2005;12(4):255-7.

321. Adefuye P. Knowledge and practice of cervical cancer screening among female professional health workers in a sub-urban district of Nigeria. Niger Med Pract. 2006;50(1):19-22.

322. Mutyaba T, Faxelid E, Mirembe F, Weiderpass E. Influences on uptake of reproductive health services in Nsangi community of Uganda and their implications for cervical cancer screening. Reprod Health. 2007;4(1):4.

323. Quentin W, Adu-Sarkodie Y, Terris-Prestholt F, Legood R, Opoku BK, Mayaud $P$. Costs of cervical cancer screening and treatment using visual inspection with acetic acid (VIA) and cryotherapy in Ghana: the importance of scale. Trop Med Int Health TM IH. 2011;16(3):379-89.

324. Goldhaber-Fiebert JD, Denny LE, De Souza M, Wright TC, Kuhn L, Goldie SJ. The costs of reducing loss to follow-up in South African cervical cancer screening. Cost Eff Resour Alloc CE. 2005;3:11.

325. Goldhaber-Fiebert JD, Goldie SJ. Estimating the cost of cervical cancer screening in five developing countries. Cost Eff Resour Alloc. 2006;4:13.

326. Williams M, Kuffour G, Ekuadzi E, Yeboah M, EIDuah M, Tuffour P. Assessment of psychological barriers to cervical cancer screening among women in Kumasi, Ghana using a mixed methods approach. Afr Health Sci. 2013;13(4):1054-61.

327. Hoque ME, Ghuman S, Coopoosmay R, Van Hal G. Cervical cancer screening among university students in South Africa: a theory based study. PLoS ONE. 2014;9(11):e111557.

328. Pengpid S, Peltzer K. Attitudes and practice of cervical cancer screening among female university students from 25 low, middle income and emerging economy countries. Asian Pac J Cancer Prev APJCP. 2014;15(17):7235-9.

329. Adonis L, An R, Luiz J, Mehrotra A, Patel D, Basu D, et al. Provincial screening rates for chronic diseases of lifestyle, cancers and HIV in a healthinsured population. South Afr Med J Suid-Afr Tydskr Vir Geneeskd. 2013; 103(5):309-12

330. Hoque ME. Awareness of cervical cancer, Papanicolau's smear and its utilization among female, final year undergraduates in Durban, South Africa. J Cancer Res Ther. 2013;9(1):25-8.

331. El Mhamdi S, Bouanene I, Mhirsi A, Bouden W, Soussi SM. Cervical cancer screening: women's knowledge, attitudes, and practices in the region of Monastir (Tunisia). Rev Dépidémiologie Santé Publique. 2012; 60(6):431-6.

332. Ndikom CM, Ofi BA. Awareness, perception and factors affecting utilization of cervical cancer screening services among women in Ibadan, Nigeria: a qualitative study. Reprod Health. 2012;9:11.

333. Hyacinth HI, Adekeye OA, Ibeh JN, Osoba T. Cervical cancer and pap smear awareness and utilization of pap smear test among Federal civil servants in North Central Nigeria. PLoS ONE. 2012;7(10):e46583.

334. Balogun MR, Odukoya OO, Oyediran MA, Ujomu PI. Cervical cancer awareness and preventive practices: a challenge for female urban slum dwellers in Lagos, Nigeria. Afr J Reprod Health. 2012;16(1):75-82.

335. Ngugi CW, Boga $H$, Muigai AWT, Wanzala $P$, Mbithi JN. Factors affecting uptake of cervical cancer early detection measures among women in Thika, Kenya. Health Care Women Int. 2012;33(7):595-613.

336. Lyimo FS, Beran TN. Demographic, knowledge, attitudinal, and accessibility factors associated with uptake of cervical cancer screening among women in a rural district of Tanzania: three public policy implications. BMC Public Health. 2012;12:22. 
337. Mbamara SU, Ikpeze OC, Okonkwo JEN, Onyiaorah IV, Ukah CO. Knowledge, attitude and practice of cervical cancer screening among women attending gynecology clinics in a tertiary level medical care center in southeastern Nigeria. J Reprod Med. 2011;56(11-12):491-6.

338. Asuzu CC, Unegbu J, Akin-Odanye E. Knowledge, attitude and behaviour of the University of Ibadan women towards cancer of the cervix and its prevention. Psychooncology. 2012;21(9):1010-5.

339. Mitchell S, Ogilvie G, Steinberg M, Sekikubo M, Biryabarema C, Money D. Assessing women's willingness to collect their own cervical samples for HPV testing as part of the ASPIRE cervical cancer screening project in Uganda. Int J Gynaecol Obstet Off Organ Int Fed Gynaecol Obstet. 2011;114(2):111-5.

340. Were E, Nyaberi Z, Buziba N. Perceptions of risk and barriers to cervical cancer screening at Moi Teaching and Referral Hospital (MTRH), Eldoret, Kenya. Afr Health Sci. 2011;11(1):58-64.

341. Mosavel M. Health promotion and cervical cancer in South Africa: why adolescent daughters can teach their mothers about early detection. Health Promot Int. 2012;27(2):157-66.

342. Nwankwo KC, Aniebue UU, Aguwa EN, Anarado AN, Agunwah E. Knowledge attitudes and practices of cervical cancer screening among urban and rural Nigerian women: a call for education and mass screening. Eur J Cancer Care (Engl). 2011;20(3):362-7.

343. Hassan FM, Khirelseed M. Cervical cancer screening among Sudanese women. Gulf J Oncolog. 2009;6:28-34.

344. Obiechina NJA, Mbamara SU. Knowledge attitude and practice of cervical cancer screening among sexually active women in Onitsha, southeast Nigeria. Niger J Med J Natl Assoc Resid Dr Niger. 2009;18(4):384-7.

345. Aniebue PN, Aniebue UU. Awareness and practice of cervical cancer screening among female undergraduate students in a Nigerian university. J Cancer Educ Off J Am Assoc Cancer Educ. 2010;25(1):106-8.

346. Dim CC, Nwagha UI, Ezegwui HU, Dim NR. The need to incorporate routine cervical cancer counselling and screening in the management of women at the outpatient clinics in Nigeria. J Obstet Gynaecol J Inst Obstet Gynaecol. 2009;29(8):754-6.

347. Mosavel M, Simon C, Oakar C, Meyer S. Cervical cancer attitudes and beliefsa Cape Town community responds on World Cancer Day. J Cancer Educ Off J Am Assoc Cancer Educ. 2009;24(2):114-9.

348. Akujobi CN, Ikechebelu Jl, Onunkwo I, Onyiaorah IV. Knowledge, attitude and practice of screening for cervical cancer among female students of a tertiary institution in South Eastern Nigeria. Niger J Clin Pract. 2008;11(3):216-9.

349. Hoque M, Ibekwe CM, Ntuli-Ngcobo B. Screening and perceived severity of cervical cancer among women attending Mahalapye District Hospital, Botswana. Asian Pac J Cancer Prev APJCP. 2009;10(6):1095-100.

350. Hoque M, Hoque E, Kader SB. Evaluation of cervical cancer screening program at a rural community of South Africa. East Afr J Public Health. 2008:5(2):111-6.

351. Ezem BU. Awareness and uptake of cervical cancer screening in Owerri, South-Eastern Nigeria. Ann Afr Med. 2007;6(3):94-8.

352. Oladepo O, Ricketts OL, John-Akinola Y. Knowledge and utilization of cervical cancer screening services among Nigerian students. Int Q Community Health Educ. 2008-2009;29(3):293-304.

353. Cronjé HS, Beyer E. Screening for cervical cancer in an African setting. Int J Gynaecol Obstet Off Organ Int Fed Gynaecol Obstet. 2007;98(2):168-71.

354. Mangoma JF, Chirenje MZ, Chimbari MJ, Chandiwana SK. An assessment of rural women's knowledge, constraints and perceptions on cervical cancer screening: the case of two districts in Zimbabwe. Afr J Reprod Health. 2006;10(1):91-103

355. Gatune JW, Nyamongo IK. An ethnographic study of cervical cancer among women in rural Kenya: is there a folk causal model? Int J Gynecol Cancer Off J Int Gynecol Cancer Soc. 2005;15(6):1049-59.

356. Hoque E, Hoque M. Knowledge of and attitude towards cervical cancer among female university students in South Africa. South Afr J Epidemiol Infect. 2009;24(1):21-4

357. Ahmed S, Ahmed R, Idris S, Sabitu K. Knowledge, attitude and practice of cervical cancer screening among market women in Zaria, Nigeria. Niger Med J. 2013;54(5):316.

358. Morema EN, Atieli HE, Onyango RO, Omondi JH, Ouma C. Determinants of cervical screening services uptake among 18-49 year old women seeking services at the Jaramogi Oginga Odinga Teaching and Referral Hospital, Kisumu, Kenya. BMC Health Serv Res. 2014;14:335.

359. Osingada CP, Ninsiima G, Chalo RN, Muliira JK, Ngabirano T. Determinants of uptake of cervical cancer screening services at a no-cost reproductive health clinic managed by nurse-midwives. Cancer Nurs. 2015;38(3):177-84.
360. Peltzer K, Phaswana-Mafuya N. Breast and cervical cancer screening and associated factors among older adult women in South Africa. Asian Pac J Cancer Prev APJCP. 2014;15(6):2473-6.

361. Adonis $L$, Basu D, Luiz J. Predictors of adherence to screening guidelines for chronic diseases of lifestyle, cancers, and HIV in a health-insured population in South Africa. Glob Health Action. 2014;7:23807.

362. Kahesa C, Kjaer S, Mwaiselage J, Ngoma T, Tersbol B, Dartell M, et al. Determinants of acceptance of cervical cancer screening in Dar es Salaam, Tanzania. BMC Public Health. 2012;12:1093.

363. Chigbu CO, Onyebuchi AK, Ajah LO, Onwudiwe EN. Motivations and preferences of rural Nigerian women undergoing cervical cancer screening via visual inspection with acetic acid. Int J Gynaecol Obstet Off Organ Int Fed Gynaecol Obstet. 2013;120(3):262-5.

364. Kahesa C, Kjaer SK, Ngoma T, Mwaiselage J, Dartell M, Iftner T, et al. Risk factors for VIA positivity and determinants of screening attendances in Dar es Salaam, Tanzania. BMC Public Health. 2012;12:1055.

365. Berraho M, Obtel M, Bendahhou K, Zidouh A, Errihani H, Benider A, et al. Sociodemographic factors and delay in the diagnosis of cervical cancer in Morocco. Pan Afr Med J. 2012;12:14.

366. Chigbu CO, Aniebue U. Why southeastern Nigerian women who are aware of cervical cancer screening do not go for cervical cancer screening. Int J Gynecol Cancer Off J Int Gynecol Cancer Soc. 2011;21(7):1282-6.

367. Chigbu CO, Aniebue UU. Non-uptake of colposcopy in a resource-poor setting. Int J Gynaecol Obstet Off Organ Int Fed Gynaecol Obstet. 2011; 113(2):100-2.

368. McKinnon B, Harper S, Moore S. Decomposing income-related inequality in cervical screening in 67 countries. Int J Public Health. 2011;56(2):139-52.

369. Bradley J, Risi L, Denny L. Widening the cervical cancer screening net in a South African township: who are the underserved? Health Care Women Int. 2004;25(3):227-41.

370. Peters LM, Soliman AS, Bukori P, Mkuchu J, Ngoma T. Evidence for the need of educational programs for cervical screening in rural Tanzania. J Cancer Educ Off J Am Assoc Cancer Educ. 2010;25(2):153-9.

371. Mahomed K, Evans D, Sauls C, Richter K, Smith J, Firnhaber C. Human papillomavirus (HPV) testing on self-collected specimens: perceptions among HIV positive women attending rural and urban clinics in South Africa. Pan Afr Med J. 2014;17:189.

372. Bateman AC, Parham GP, Sahasrabuddhe W, Mwanahamuntu MH, Kapambwe S, Katundu K, et al. Clinical performance of digital cervicography and cytology for cervical cancer screening in HIV-infected women in Lusaka, Zambia. J Acquir Immune Defic Syndr. 2014;67(2):212-5.

373. Ngou J, Magooa MP, Gilham C, Djigma F, Didelot M-N, Kelly H, et al. Comparison of careHPV and hybrid capture 2 assays for detection of highrisk human Papillomavirus DNA in cervical samples from HIV-1-infected African women. J Clin Microbiol. 2013;51(12):4240-2.

374. Chung MH, McKenzie KP, De Vuyst H, Richardson BA, Rana F, Pamnani R, et al. Comparing Papanicolau smear, visual inspection with acetic acid and human papillomavirus cervical cancer screening methods among HIVpositive women by immune status and antiretroviral therapy. AIDS Lond Engl. 2013;27(18):2909-19.

375. Firnhaber C, Mayisela N, Mao L, Williams S, Swarts A, Faesen M, et al. Validation of cervical cancer screening methods in HIV positive women from Johannesburg South Africa. PLoS ONE. 2013;8(1):e53494.

376. Mabeya H, Khozaim K, Liu T, Orango O, Chumba D, Pisharodi L, et al. Comparison of conventional cervical cytology versus visual inspection with acetic acid among human immunodeficiency virus-infected women in Western Kenya. J Low Genit Tract Dis. 2012;16(2):92-7.

377. Kitchener H, Nelson L, Adams J, Mesher D, Sasieni P, Cubie H, et al. Colposcopy is not necessary to assess the risk to the cervix in HIV-positive women: an international cohort study of cervical pathology in HIV-1 positive women. Int J Cancer J Int Cancer. 2007;121(11):2484-91.

378. De Vuyst H, Chung MH, Baussano I, Mugo NR, Tenet V, van Kemenade FJ, et al. Comparison of HPV DNA testing in cervical exfoliated cells and tissue biopsies among HIV-positive women in Kenya. Int J Cancer J Int Cancer. 2013;133(6):1441-6.

379. Bansil P, Lim J, Byamugisha J, Kumakech E, Nakisige C, Jeronimo JA. Performance of Cervical Cancer Screening Techniques in HIV-Infected Women in Uganda. J Low Genit Tract Dis. 2015;19(3):215-9.

380. Ogilvie GS, Mitchell S, Sekikubo M, Biryabarema C, Byamugisha J, Jeronimo $J$, et al. Results of a community-based cervical cancer screening pilot project using human papillomavirus self-sampling in Kampala, Uganda. Int J Gynaecol Obstet Off Organ Int Fed Gynaecol Obstet. 2013;122(2):118-23. 
381. Tum SJ, Maree JE, Clarke M. Creating awareness and facilitating cervical and breast cancer screening uptake through the use of a Community Health Worker: a pilot intervention study. Eur J Cancer Care (Engl). 2013;22(1):107-16.

382. Sankaranarayanan R, Sauvaget C, Ramadas K, Ngoma T, Teguete I, Muwonge $\mathrm{R}$, et al. Clinical trials of cancer screening in the developing world and their impact on cancer healthcare. Ann Oncol Off J Eur Soc Med Oncol ESMO. 2011;22 Suppl 7:vii20-8.

383. Teguete I, Muwonge R, Traore CB, Dolo A, Bayo S, Sankaranarayanan R. Can visual cervical screening be sustained in routine health services? Experience from Mali, Africa. BJOG Int J Obstet Gynaecol. 2012;119(2):220-6.

384. Were E, Nyaberi Z, Buziba N. Integrating cervical cancer and genital tract infection screening into mother, child health and family planning clinics in Eldoret, Kenya. Afr Health Sci. 2010;10(1):58-65.

385. Goldhaber-Fiebert JD, Denny LA, De Souza M, Kuhn L, Goldie SJ. Program spending to increase adherence: South African cervical cancer screening. PLoS ONE. 2009:4(5):e5691.

386. Shinn E, Basen-Engquist K, Crain B, Follen M. A theory-aided dissemination strategy for emerging technologies in cervical cancer screening. Gyneco Oncol. 2007;107(1):S35-9.

387. Roblyer D, Richards-Kortum R, Park S-Y, Adewole I, Follen M. Objective screening for cervical cancer in developing nations: lessons from Nigeria Gynecol Oncol. 2007;107(1 Suppl 1):S94-7.

388. Obi SN, Ozumba BC, Nwokocha AR, Waboso PA. Participation in highly subsidized cervical cancer screening by women in Enugu, South-east Nigeria. J Obstet Gynaecol J Inst Obstet Gynaecol. 2007;27(3):305-7.

389. Hamad HMA. Cancer initiatives in Sudan. Ann Oncol Off J Eur Soc Med Oncol ESMO. 2006:17 Suppl 8:viii32-6.

390. Knight B. Project: screen South Africa. Diagn Cytopathol. 2005;33(5):356-8.

391. Adewole IF, Benedet JL, Crain BT, Follen M. Evolving a strategic approach to cervical cancer control in Africa. Gynecol Oncol. 2005;99(3 Suppl 1):S209-12.

392. Cronjé HS. Screening for cervical cancer in the developing world. Best Pract Res Clin Obstet Gynaecol. 2005;19(4):517-29.

393. Thomas JO, Babarinsa IA, Ajayi IO, Fawole O, Ojemakinde KO, Omigbodun AO. Mobilization for cervical cancer screening: lessons from a poor-urban Yoruba community in Nigeria. Afr J Med Med Sci. 2005:34(1):81-5.

394. Richter K. Understanding and incorporating human papillomavirus testing in cervical cancer screening : a South African perspective : review. South Afr J Gynaecol Oncol. 2011;3(1):9-14.

395. Risi L, Bindman JP, Campbell OMR, Imrie J, Everett K, Bradley J, et al. Media interventions to increase cervical screening uptake in South Africa: an evaluation study of effectiveness. Health Educ Res. 2004;19(4):457-68.

396. Ezechi OC, Petterson KO, Gbajabiamila TA, Idigbe IE, Kuyoro O, Ujah IAO, et al. Predictors of default from follow-up care in a cervical cancer screening program using direct visual inspection in south-western Nigeria. BMC Health Serv Res. 2014;14:143.

397. Knegt Y. Audit of cervical cancer screening and colposcopy attendance in rural South Africa. Afr J Reprod Health. 2014;18(4):70-8.

398. Okonkwo CA, Ezeanochie MC, Olagbuji BN. Physical after effects and clients satisfaction following colposcopy and cervical biopsy in a Nigerian population. Afr Health Sci. 2013;13(2):402-6.

399. Sancho-Garnier H, Khazraji YC, Cherif MH, Mahnane A, Hsairi M, El Shalakamy A, et al. Overview of cervical cancer screening practices in the extended Middle East and North Africa countries. Vaccine. 2013;31 Suppl 6:G51-7.

400. Brower V. AIDS-Related Cancers Increase in Africa. JNCI J Natl Cancer Inst. 2011;103(12):918-9.

401. Bosu WK. A comprehensive review of the policy and programmatic response to chronic non-communicable disease in Ghana. Ghana Med J. 2012;46(2 Suppl):69-78.

402. Denny L. Cervical cancer: the South African perspective. FIGO 26th Annual Report on the Results of Treatment in Gynecological Cancer. Int J Gynaecol Obstet Off Organ Int Fed Gynaecol Obstet. 2006:95 Suppl 1:S211-4

403. Omondi Aduda DS, Mkhize N. Ethical issues evolving from patients' perspectives on compulsory screening for syphilis and voluntary screening for cervical cancer in Kenya. BMC Med Ethics. 2014;15:27.

404. Maree JE, Wright SCD. Cervical cancer: does our message promote screening? A pilot study in a South African context. Eur J Oncol Nurs Off J Eur Oncol Nurs Soc. 2011;15(2):118-23.

405. Kennedy A. Integrating cervical cancer prevention in HIV/AIDS treatment and care programmes. Bull World Health Organ. 2008;86(8):656-6.
406. Ditzian LR, David-West G, Maza M, Hartmann B, Shirazian T, Cremer M Cervical Cancer Screening in Low- and Middle-Income Countries. Mt Sinai J Med J Transl Pers Med. 2011;78(3):319-26.

407. Maree J, Schmollgruber S. An integrative review of South African cancer nursing research published from 2002-2012. Curationis. 2014;37(1):E1-10.

408. Adam Y, van Gelderen CJ, de Bruyn G, Mclntyre JA, Turton DA, Martinson NA. Predictors of persistent cytologic abnormalities after treatment of cervical intraepithelial neoplasia in Soweto, South Africa: a cohort study in a HIV high prevalence population. BMC Cancer. 2008;8:211.

409. Adam Y, van Gelderen CJ, Newell K. "Look and Lletz"-a Chris Hani Baragwanath Hospital experience. South Afr Med J Suid-Afr Tydskr Vir Geneeskd. 2008;98(2):119-22.

410. Lindeque BG. Management of cervical premalignant lesions. Best Pract Res Clin Obstet Gynaecol. 2005;19(4):545-61.

411. Lewis KDC, Sellors JW, Dawa A, Tsu VD, Kidula NA. Report on a cryotherapy service for women with cervical intraepithelial neoplasia in a district hospita in western Kenya. Afr Health Sci. 2011:11(3):370-6.

412. Chamot E, Kristensen S, Stringer JSA, Mwanahamuntu MH. Are treatments for cervical precancerous lesions in less-developed countries safe enough to promote scaling-up of cervical screening programs? A systematic review. BMC Womens Health. 2010;10:11.

413. Anorlu RI, Orakwue CO, Oyeneyin L, Abudu OO. Late presentation of patients with cervical cancer to a tertiary hospital in Lagos: what is responsible? Eur J Gynaecol Oncol. 2004;25(6):729-32.

414. Anunobi CC, Jagun OE, Agboola AO, Akintola PA, Andu BA. Clinicopathological study of female genital malignancies in Olabisi Onabanjo University Teaching Hospital, Sagamu, Ogun State, Nigeria. West Afr J Med. 2014:33(1):7-11.

415. Ikechebelu Jl, Onyiaorah IV, Ugboaja JO, Anyiam DCD, Eleje GU Clinicopathological analysis of cervical cancer seen in a tertiary health facility in Nnewi, south-east Nigeria. J Obstet Gynaecol J Inst Obstet Gynaecol. 2010;30(3):299-301.

416. Missaoui N, Hmissa S, Trabelsi A, Frappart L, Mokni M, Korbi S. Cervix cancer in Tunisia: clinical and pathological study. Asian Pac J Cancer Prev APJCP. 2010;11(1):235-8.

417. Onah HE, lyoke CA. Abnormal Pap smears: a comparison of total abdominal hysterectomy and cone biopsy in management. J Obstet Gynaecol J Inst Obstet Gynaecol. 2006;26(1):48-51.

418. Dreyer G. Operative management of cervical cancer. Best Pract Res Clin Obstet Gynaecol. 2005;19(4):563-76.

419. Einck JP, Hudson A, Shulman AC, Yashar CM, Dieng MM, Diagne M, et al. Implementation of a high-dose-rate brachytherapy program for carcinoma of the cervix in Senegal: a pragmatic model for the developing world. Int J Radiat Oncol Biol Phys. 2014;89(3):462-7.

420. Dreyer G, Snyman LC, Mouton A, Lindeque BG. Management of recurrent cervical cancer. Best Pract Res Clin Obstet Gynaecol. 2005;19(4):631-44.

421. Mubangizi L, Namusoke F, Mutyaba T. Aerobic cervical bacteriology and antibiotic sensitivity patterns in patients with advanced cervical cancer before and after radiotherapy at a national referral hospital in Uganda. Int J Gynaecol Obstet Off Organ Int Fed Gynaecol Obstet. 2014;126(1):37-40.

422. Denny L. Cervical cancer treatment in Africa. Curr Opin Oncol. 2011;23(5):469-74.

423. Nyongesa C, Ruff P, Donde B, Kotzen J. A phase I study of concurrent cisplatin chemotherapy in patients with carcinoma of the cervix receiving pelvic radiotherapy. Int J Gynecol Cancer Off J Int Gynecol Cancer Soc. 2006;16(4):1614-9.

424. Msyamboza KP, Manda G, Tembo B, Thambo C, Chitete L, Mindiera C, et al. Cancer survival in Malawi: a retrospective cohort study. Pan Afr Med J. 2014; 19:234.

425. Gondos A, Brenner H, Wabinga H, Parkin DM. Cancer survival in Kampala, Uganda. Br J Cancer. 2005;92(9):1808-12.

426. Alleyne-Mike K, van Wijk L, Hunter A. A retrospective review of patients with stage IB2 cervical cancer treated with radical radiation versus radical surgery as a primary modality. Int J Gynecol Cancer Off J Int Gynecol Cancer Soc. 2013;23(7):1287-94.

427. Osman M. The role of neoadjuvant chemotherapy in the management of locally advanced cervix cancer: a systematic review. Oncol Rev. 2014:8(2):250.

428. Sankaranarayanan R, Swaminathan R, Brenner H, Chen K, Chia KS, Chen JG, et al. Cancer survival in Africa, Asia, and Central America: a populationbased study. Lancet Oncol. 2010;11(2):165-73. 
429. Kabir F, van Gelderen C, McIntyre J, Michelow P, Turton D, Adam Y. Cervical intra-epithelial neoplasia in HIV-positive women after excision of transformation zone - does the grade change? South Afr Med J Suid-Afr Tydskr Vir Geneeskd. 2012;102(9):757-60.

430. Woo VG, Liegler T, Cohen CR, Sawaya GF, Smith-McCune K, Bukusi EA, et al. Association of cervical biopsy with HIV type 1 genital shedding among women on highly active antiretroviral therapy. AIDS Res Hum Retroviruses. 2013;29(7):1000-5.

431. Jaquet A, Horo A, Ekouevi DK, Toure B, Coffie PA, Effi B, et al. Risk factors for cervical intraepithelial neoplasia in HIV-infected women on antiretroviral treatment in Côte d'Ivoire, West Africa. PLoS ONE. 2014;9(3):e90625.

432. Omar T, Schwartz S, Hanrahan C, Modisenyane T, Tshabangu N, Golub $\mathrm{JE}$, et al. Progression and regression of premalignant cervical lesions in HIV-infected women from Soweto: a prospective cohort. AIDS Lond Engl. 2011;25(1):87-94.

433. van Bogaert L-JJ. Age at diagnosis of preinvasive and invasive cervical neoplasia in South Africa: HIV-positive versus HIV-negative women. Int J Gynecol Cancer Off J Int Gynecol Cancer Soc. 2011;21(2):363-6.

434. Odendal L. Cervical cancer in women with HIV [Internet]. HIV \& AIDS Treatment in Practice; 2011 [cited 2015 Jul 10]. Available from: http://www. aidsmap.com/pdf/HATIP-174-February-17th-2011/page/1669154/. Accessed 6 July 2015.

435. Holmes RS, Hawes SE, Touré P, Dem A, Feng Q, Weiss NS, et al. HIV infection as a risk factor for cervical cancer and cervical intraepithelial neoplasia in Senegal. Cancer Epidemiol Biomark Prev Publ Am Assoc Cancer Res Cosponsored Am Soc Prev Oncol. 2009;18(9):2442-6.

436. Moodley M. Radical hysterectomy for cervical cancer amongst women infected with the human immunodeficiency virus. Int J Gynecol Cancer Off J Int Gynecol Cancer Soc. 2007;17(6):1264-5.

437. Moodley M. Cervical cancer in Southern Africa: The challenges. SA J Gynaecol Oncol. 2009;1:1.

438. Elit LM, Rosen B, Jimenez W, Giede C, Cybulska P, Sinasac S, et al. Teaching cervical cancer surgery in low- or middle-resource countries. Int J Gynecol Cancer Off J Int Gynecol Cancer Soc. 2010;20(9):1604-8.

439. Nwogu C, Mahoney M, George S, Dy G, Hartman H, Animashaun M, et al. Promoting cancer control training in resource limited environments: Lagos, Nigeria. J Cancer Educ Off J Am Assoc Cancer Educ. 2014;29(1):14-8.

440. van Schalkwyk SL, Maree JE, Wright SCD. Cervical cancer: the route from signs and symptoms to treatment in South Africa. Reprod Health Matters. 2008;16(32):9-17.

441. Williams CK, Cristina Stefan D, Rawlinson F, Simbiri K, Mbulaiteye SM. The African Organisation for Research and Training in Cancer and its conferences: a historical perspective and highlights of the Ninth International Conference, Durban, South Africa, 21-24 November 2013. Ecancermedicalscience. 2014;8:396.

442. Kerr D, Flander A. Towards Prevention of Cervical Cancer in Africa Report from Meeting at St. Catherine's College, Oxford [Internet]. Oxford, UK: AFROX; 2009 [cited 2015 Jul 10]. Available from: http://www.afrox.org/ uploads/asset_file/Towards\%20the\%20Prevention\%20of\%20Cervical\%20 Cancer\%20in\%20Africa\%20-\%20Conference\%20Report.pdf

443. Abdel-Wahab M, Bourque J-M, Pynda Y, Iżewska J, Van der Merwe D, Zubizarreta E, et al. Status of radiotherapy resources in Africa: an International Atomic Energy Agency analysis. Lancet Oncol. 2013;14(4):e168-75.

444. Bvochara-Nsingo M, Grover S, Gierga DP, Makufa R, Efstathiou JA, Dixit N, et al. Cervical Brachytherapy Exchange: Steps Toward Oncology Capacity Building in Botswana. Oncologist. 2014;19(7):e1-2.

445. Anorlu RI. Cervical cancer: the sub-Saharan African perspective. Reprod Health Matters. 2008;16(32):41-9.

446. McArdle O, Kigula-Mugambe JB. Contraindications to cisplatin based chemoradiotherapy in the treatment of cervical cancer in Sub-Saharan Africa. Radiother Oncol J Eur Soc Ther Radiol Oncol. 2007;83(1):94-6.

447. Government of the Republic of Zambia. The 6th Stop Cervical Cancer in Africa Conference Report [Internet]. Lusaka, Zambia; 2013. Available from: http://pinkribbonredribbon.org/wp-content/uploads/6th-SCCA-Report.pdf. Accessed 6 July 2015.

448. Berraho M, Najdi A, Mathoulin-Pelissier S, Salamon R, Nejjari C. Direct costs of cervical cancer management in Morocco. Asian Pac J Cancer Prev APJCP. 2012;13(7):3159-63.

449. Ben Gobrane H, Aounallah-Skhiri H, Oueslati F, Frikha H, Achour N, Hsairi M. Estimated cost of managing invasive cervical cancer in Tunisia. Santé Publique Vandoeuvre-Lès-Nancy Fr. 2009;21(6):561-9.
450. Selman L, Siegert RJ, Higginson IJ, Agupio G, Dinat N, Downing J, et al. The "Spirit 8" successfully captured spiritual well-being in African palliative care: factor and Rasch analysis. J Clin Epidemiol. 2012;65(4):434-43.

451. Selman LE, Higginson IJ, Agupio G, Dinat N, Downing J, Gwyther L, et al. Quality of life among patients receiving palliative care in South Africa and Uganda: a multi-centred study. Health Qual Life Outcomes. 2011;9:21.

452. Awadalla AW, Ohaeri JU, Gholoum A, Khalid AOA, Hamad HMA, Jacob A. Factors associated with quality of life of outpatients with breast cancer and gynecologic cancers and their family caregivers: a controlled study. BMC Cancer. 2007;7:102.

\section{Submit your next manuscript to BioMed Central and we will help you at every step:}

- We accept pre-submission inquiries

- Our selector tool helps you to find the most relevant journal

- We provide round the clock customer support

- Convenient online submission

- Thorough peer review

- Inclusion in PubMed and all major indexing services

- Maximum visibility for your research

Submit your manuscript at www.biomedcentral.com/submit
C Biomed Central 